\title{
Geochemical Signature of Magmatic-Hydrothermal Fluids Exsolved from the Beauvoir Rare-Metal Granite (Massif Central, France): Insights from LA-ICPMS Analysis of Primary Fluid Inclusions
}

\author{
Matthieu Harlaux, Julien Mercadier, Wilédio Marc-Emile Bonzi, \\ Valentin Kremer, Christian Marignac, and Michel Cuney
}

Université de Lorraine, CNRS, CREGU, GeoRessources, 54506 Vandouvre-lès-Nancy, France

Correspondence should be addressed to Matthieu Harlaux; matthieu.harlaux@unige.ch

Received 15 August 2017; Accepted 7 November 2017; Published 26 December 2017

Academic Editor: Xing Ding

Copyright (C) 2017 Matthieu Harlaux et al. This is an open access article distributed under the Creative Commons Attribution License, which permits unrestricted use, distribution, and reproduction in any medium, provided the original work is properly cited.

\begin{abstract}
The Beauvoir granite (Massif Central, France) represents an exceptional case in the European Variscan belt of a peraluminous raremetal granite crosscutting an early W stockwork. The latter was strongly overprinted by rare-metal magmatic-hydrothermal fluids derived from the Beauvoir granite, resulting in a massive topazification of the quartz-ferberite vein system. This work presents a complete study of primary fluid inclusions hosted in quartz and topaz from the Beauvoir granite and the metasomatized stockwork, in order to characterize the geochemical composition of the magmatic fluids exsolved during the crystallization of this evolved rare-metal peraluminous granite. Microthermometric and Raman spectrometry data show that the earliest fluid (L1) is of high temperature $\left(500\right.$ to $\left.>600^{\circ} \mathrm{C}\right)$, high salinity $\left(17-28 \mathrm{wt} . \% \mathrm{NaCl}\right.$ eq), and Li-rich $\left(T_{\mathrm{e}}<-70^{\circ} \mathrm{C}\right)$ with $\mathrm{Na} / \mathrm{Li}$ ratios $\sim 5$. LA-ICPMS analyses of L1-type fluid inclusions reveal that the chemical composition of this magmatic-hydrothermal fluid is dominated by $\mathrm{Na}$, $\mathrm{K}, \mathrm{Cs}$, and $\mathrm{Rb}$, with significant concentrations $\left(10^{1}-10^{4} \mathrm{ppm}\right)$ in rare-metals $(\mathrm{W}, \mathrm{Nb}, \mathrm{Ta}, \mathrm{Sn}$, and $\mathrm{Li})$. This study demonstrates that primary fluid inclusions preserved the pristine signature of the magmatic-hydrothermal fluids in the Beauvoir granite but also in the metasomatized W stockwork, despite the distance from the granitic cupola $(>100 \mathrm{~m})$ and interaction with external fluids.
\end{abstract}

\section{Introduction}

Rare-metal deposits are mainly associated with peraluminous to peralkaline granites, granitic pegmatites, and carbonatite complexes, which represent major resources for economically strategic metals such as $\mathrm{Li}, \mathrm{Be}, \mathrm{Ta}, \mathrm{Nb}, \mathrm{Sn}, \mathrm{W}$, and REE $[1,2]$. Among these deposits, the LCT (Lithium-CaesiumTantalum) class of rare-element pegmatites (RMP) and the peraluminous high- and low-phosphorous rare-metal granites (PHP- and PLP-RMG, resp.) constitute the two major groups of rare-metal mineralization [2-5]. In Europe, the Variscan belt represents an important metallogenic province for these two types of rare-metal deposits, which are located mainly in the Bohemian Massif, the Iberian Massif, Cornwall, the Armorican Massif, and the French Massif Central (FMC).
These deposits formed during Carboniferous to Permian times between $330 \mathrm{Ma}$ and $280 \mathrm{Ma}$ in relation to the lateVariscan orogenic evolution [6-10]. In France, the Beauvoir granite represents one of the best examples of a PHP-RMG with a disseminated $\mathrm{Sn}-\mathrm{Li}-\mathrm{Ta}-\mathrm{Nb}-\mathrm{Be}$ mineralization [5] and was intensively studied during the 1980s-1990s, with the $900 \mathrm{~m}$ of continuous core drilling GPF1 from the "Géologie Profonde de la France" program [11]. These studies led to a complete petrological, geochemical, geophysical, structural, and geochronological description of the Beauvoir granite and of its host-environment and to the elaboration of integrated genetic model for this type of rare-metal deposit $[12,13]$.

The magmatic-hydrothermal evolution of RMG systems is relatively well constrained from a large number of works 
based both on natural examples (e.g., [12-15]) and experimental works (e.g., [3, 16-19]). The extreme rare-metal enrichment in these highly peraluminous granitic magmas has generally been interpreted as resulting from crystal fractionation [5]. Deciphering the geochemical composition of the magmatic fluids exsolved from RMG is thus essential to better understand the behaviour of the chemical elements during the late-stage of crystallization and their partitioning between the melt and the fluid phases at the magmatichydrothermal transition. Most of these data were obtained from silicate melt inclusion studies, which are considered to represent direct analogues of the composition of the crystallizing magma (e.g., [20-26]). These works reported that latestage residual melts are enriched in $\mathrm{H}_{2} \mathrm{O}$, fluxing elements (B, $\mathrm{F}$, and $\mathrm{P}$ ) and incompatible elements (e.g., $\mathrm{Be}, \mathrm{Sn}, \mathrm{Rb}, \mathrm{Cs}, \mathrm{Nb}$, $\mathrm{Ta}$, and $\mathrm{Li}$ ) and reflect the whole-rock bulk composition of the host-granite. At the magmatic-hydrothermal transition, residual fluid yields to phase separation of a low-density vapour phase and a high-density brine [18, 19]. Analysis of the composition of coexisting melt and fluid inclusions trapped during phase separation in low phosphorus RMG showed that most of the trace elements partition into the aqueous fluid phase [21,25]. However, few data remain available about the trace element composition of fluid inclusions in such magmatic-hydrothermal systems (e.g., [27-29]).

The aims of this work are consequently (i) to determine the trace element composition of the magmatic fluid inclusions trapped in primary quartz and topaz crystals from the Beauvoir granite and to characterize the geochemical signature of these rare-metal-rich magmatic fluids; (ii) to study the partitioning of the minor and trace elements between the coexisting vapour and brine phases resulting from the phase separation during the boiling of the early primary magmatic fluid; (iii) to determine the chemical evolution of the magmatic fluids exsolved from the Beauvoir granite during their interaction with the enclosing micaschists with distance from the granitic cupola.

\section{Geological Setting}

2.1. Regional Geology of the North French Massif Central. The Beauvoir granite is located in the Echassières granitic complex in the NE part of the FMC in the Limousin area (Figure 1), which belongs to the internal zone of the European Variscan belt and results from the continental collision between Gondwana and Laurussia during the Upper Paleozoic. The structure of the FMC has been recognized as a stack of metamorphic nappes developed diachronously from Late Silurian to Early Carboniferous, which is constituted by three major tectonic units that are from the north to the south and from top to bottom ([30] and references therein): (i) the Upper Gneiss Unit (UGU), which is composed of migmatitic ortho- and paragneisses and contains the so-called "leptyniteamphibolite complex," formed by the bimodal association of mafic/ultramafic rocks with felsic rocks; (ii) the Lower Gneiss Unit (LGU) which consists of ortho- and paragneisses similar to those of the UGU; and (iii) the Para-Autochthonous Unit (PAU), dominated by metasedimentary units (micaschists, metagreywackes, and quartzites) that experienced low-grade metamorphism. To the south, these metamorphic units are overthrusted onto the nonmetamorphic rocks of the external zone with its fold-and-thrust belt and its foreland basin.

The Echassières granitic complex intrudes into the Sioule metamorphic series, which is delimited to the west by the Late Carboniferous Sillon Houiller sinistral wrench fault and to the east by the Oligocene Ebreuil and Limagne grabens (Figure 1). The Sioule metamorphic series is located at the northern boundary of the Guéret, St-Gervais, Manzat, and Champ-Valmont granites, which represent large peraluminous cordierite-biotite intrusions emplaced during the Late Devonian to Early Carboniferous at ca. 360-350 Ma [31, 32]. To the south of the Echassières granitic complex, another type of intrusion of biotite porphyritic subalkaline granite (Pouzol-Servant) is emplaced at ca. 330-340 Ma [33]. The Sioule metamorphic series is composed by three lithostructural units, which are from top to bottom [34]: (i) an upper unit of cordierite-bearing migmatite and biotite-sillimanite gneiss, corresponding to the UGU; (ii) an intermediate unit composed by biotite-muscovite paragneiss, corresponding to the LGU; and (iii) a lower unit formed by biotite-muscovite micaschists, which is correlated with the PAU. This series experienced two major synmetamorphic events $[35,36]$ : (i) a HP $D_{0}$ event coeval with eclogitic-granulitic metamorphism at ca. $430-400 \mathrm{Ma}$; and (ii) a MP-MT $D_{2}$ event coeval with the top-to-the-NW shearing at ca. 365-350 Ma.

\subsection{Structure and Age of the Echassières Granitic Complex.} The Echassières granitic complex includes an early W-bearing quartz-vein system, the so-called La Bosse stockwork, and at least three successive granitic units that intruded into the micaschists of the PAU [12,13]. From oldest to youngest, these granitic units are (Figure 2): (i) the La Bosse granite, which is concealed at depth and is presumed to be related to the formation of the $\mathrm{W}$ deposit; (ii) the Colettes granite, which is a porphyritic biotite-muscovite-cordierite granite that overprints the La Bosse stockwork; and (iii) the Beauvoir granite, which consists of a topaz-lepidolite-albite granite with disseminated $\mathrm{Sn}-\mathrm{Li}-\mathrm{Ta}-\mathrm{Nb}-\mathrm{Be}$ mineralization that crosscuts the Colettes granite. The GPF1 drill hole intersected the roof and bottom of the Beauvoir granite at depths of $-100 \mathrm{~m}$ and $-880 \mathrm{~m}$, respectively, below the current surface [11]. This drill hole allowed the identification of a vertical internal zoning in the Beauvoir granite (Figure 2) with three main granitic units emplaced successively, which are separated by magmatic layering and show a magmatic foliation underlined by lepidolite. From the lowest to the upper, these units are [12, 13] (i) $\mathrm{B} 3$ facies ( -880 to $-750 \mathrm{~m}$ ), which contains euhedral pink-colored K-feldspars, zinnwaldites, and hosts commonly micaschists enclaves with quartz-ferberite veins; (ii) B2 facies $(-750$ to $-450 \mathrm{~m})$ consisting of a lepidolite-rich granular granite with idiomorphic quartz crystals and small amounts of K-feldspars; (iii) B1 facies ( -450 to $-100 \mathrm{~m}$ ) corresponding to an albite-lepidolite-rich granite containing globular quartz crystals with typical "snowball" textures and rare anhedral perthitic K-feldspars. Generally, the abundance of accessory minerals (topaz, cassiterite, columbite-tantalite, microlite, and $\mathrm{Li}-\mathrm{Be}$ phosphates) tends to increase upward from the $\mathrm{B} 3$ to the B1 facies, the latter being the most evolved. This 


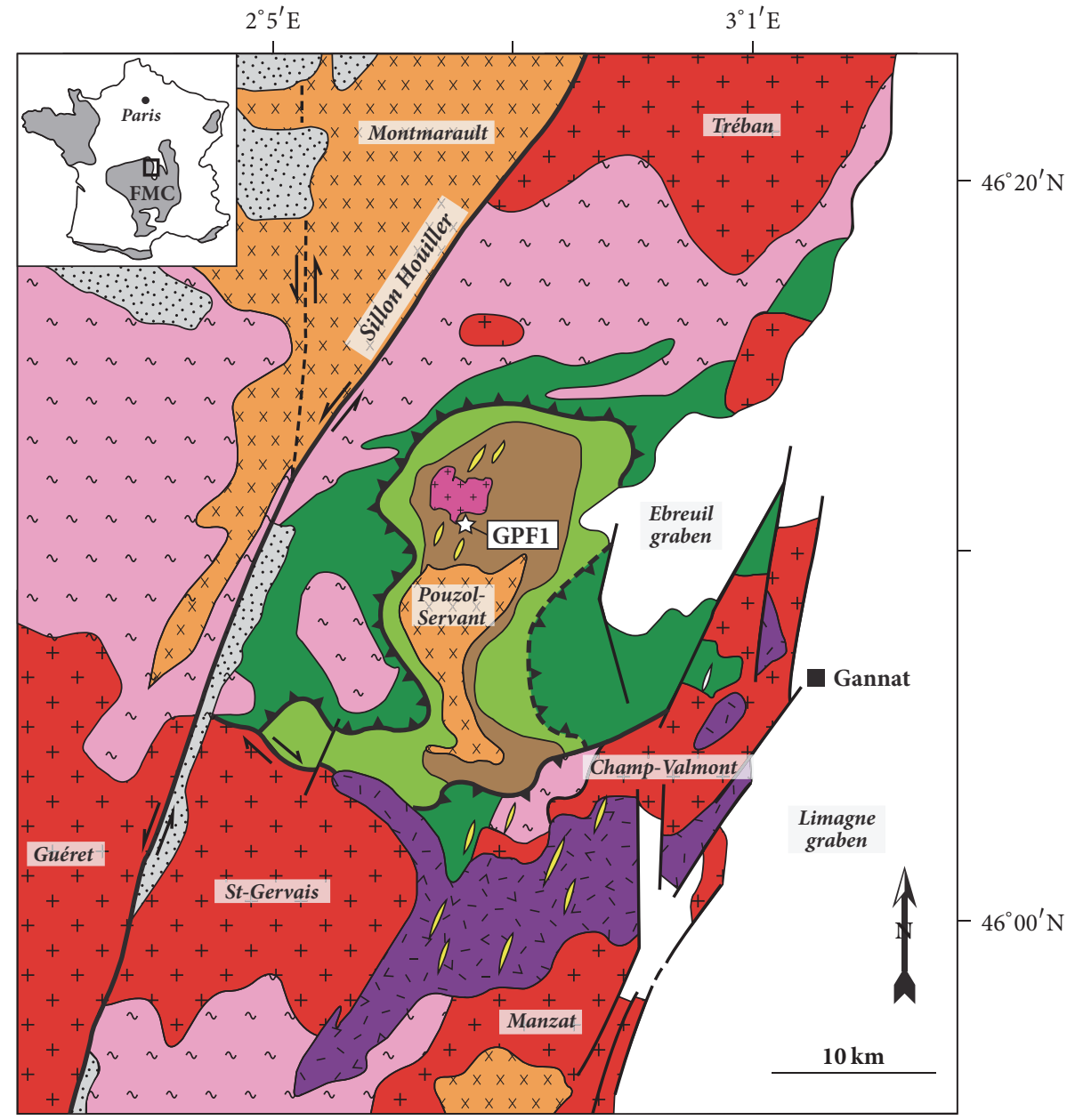

Explanation

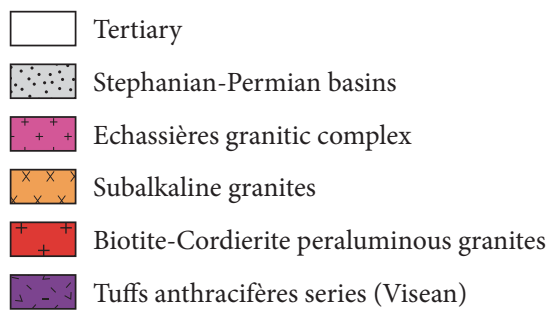

Upper Gneiss Unit (UGU)

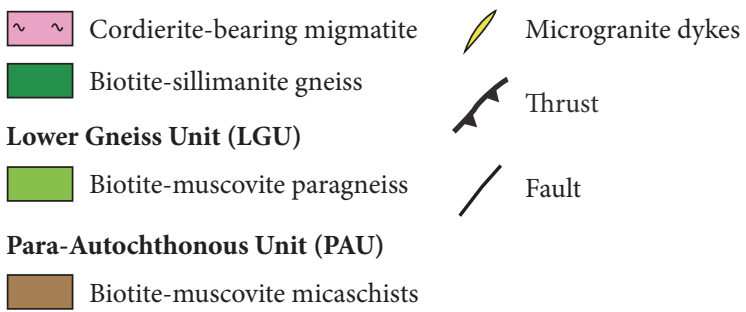

FIGURE 1: Geological setting of the Echassières granitic complex in the NE part of the French Massif Central (FMC) (modified from [11]). The location of the GPF1 drill hole from the "Géologie Profonde de la France" program is indicated.

evolution reflects the progressive increase in trace element contents (200-1,200 ppm Sn, 50-150 ppm Nb, 30-300 ppm Ta, 20-70 ppm W, 200-600 ppm Cs, 25-500 ppm Be, and $700-2,800 \mathrm{ppm} \mathrm{Li}$ ) in whole-rock geochemistry that has been interpreted as a magmatic differentiation trend upward $[12,13]$. The Echassières granitic complex, with an outcrop extension of ca. $40 \mathrm{~km}^{2}$, was estimated from gravimetric data to be 3 to $4 \mathrm{~km}$ thick, with an overall volume of ca. $65 \mathrm{~km}^{3}$ [37]. The Beauvoir granite, outcropping over $0.10 \mathrm{~km}^{2}$, was estimated of a minimum volume of ca. $0.21 \mathrm{~km}^{3}$ [13] and was emplaced as a sheet intruded into the micaschists and the Echassières granitic complex (Figure 2). Nowadays, the upper parts of the Beauvoir and Colettes granites are strongly kaolinized and are mined in open-pit quarry for kaolin by the company Imerys Ceramics France producing $20 \mathrm{kt} / \mathrm{yr}$ of kaolin as well as $\sim 60 \mathrm{t} / \mathrm{yr}$ of mineral concentrates of cassiterite, columbite-tantalite, and microlite as by-products.

The emplacement of the Beauvoir granite has been dated at $308 \pm 2 \mathrm{Ma}$, based on ${ }^{40} \mathrm{Ar}^{-}{ }^{39}$ Ar dating of lepidolite from the $\mathrm{B} 1$ facies [38]. However, a recent U-Pb dating of columbitetantalite from the same facies yielded an age of $317 \pm 6 \mathrm{Ma}$ [10], which is slightly older than the previous age. This age 


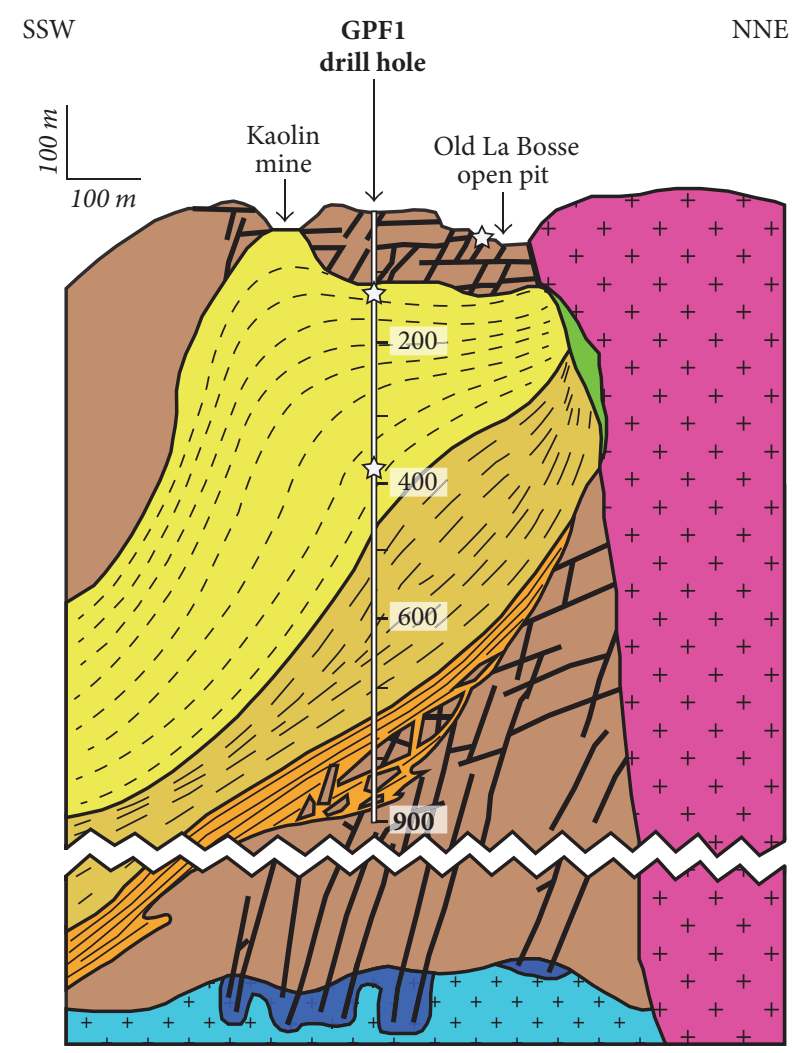

Explanation

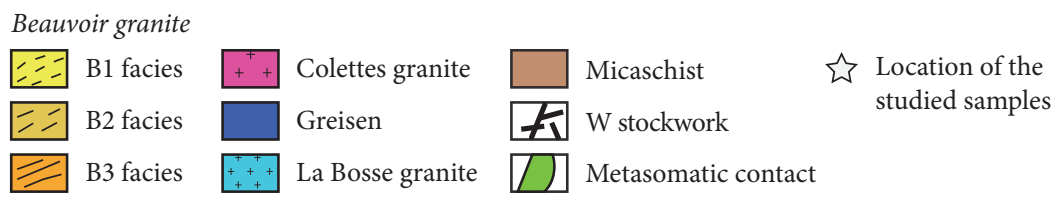

FIGURE 2: Interpretative cross-section of the Beauvoir granite from the GPF1 drill hole showing the vertical magmatic internal zoning composed by the three successive facies B1, B2, and B3 (modified from [12]). The location of the samples studied in this work is also reported.

discrepancy raises therefore the question of the reliability of the lepidolite age and the eventual existence of a perturbing thermal event, which could have partially reset the ${ }^{40} \mathrm{Ar}^{39} \mathrm{Ar}$ isotopic system of micas. Indeed, lepidolite is partly replaced by Li-muscovite in the $\mathrm{B} 1$ facies, which has been interpreted as a subsolidus fluid-rock interaction resulting from the mixing of the magmatic fluid exsolved from the granite with an external fluid at high temperature during the late stages of the Beauvoir granite emplacement [12]. There is no known high-temperature event after dating the emplacement of the Beauvoir granite, which could have reopened the ${ }^{40} \mathrm{Ar}$ ${ }^{39} \mathrm{Ar}$ isotopic system of micas. A series of lower temperature hydrothermal stages are described in the B1 granite [39], but the earliest event following the Li-muscovite alteration has been dated from the Upper Jurassic at $151 \pm 4 \mathrm{Ma}$ (K-Ar on illite [39]) and was too low in temperature $\left(T \leq 250^{\circ} \mathrm{C}\right)$ to reset the ${ }^{40} \mathrm{Ar}^{39} \mathrm{Ar}$ isotopic system of micas. Therefore, the ${ }^{40} \mathrm{Ar}-{ }^{39} \mathrm{Ar}$ age obtained on lepidolite seems reliable and an emplacement age of ca. $310 \mathrm{Ma}$ for the Beauvoir granite is consistent within uncertainty with the two existing $\mathrm{U}-\mathrm{Pb}$ and ${ }^{40} \mathrm{Ar}^{-}{ }^{39}$ Ar ages.

The La Bosse W stockwork consists in a network of up to $0.6 \mathrm{~m}$-thick quartz-ferberite veins, which are hosted in the micaschists of the PAU and have been dated at $334 \pm 2 \mathrm{Ma}$ (U-Pb on wolframite [40]). The micaschists and the hosted W stockwork are crosscut by the Colettes and Beauvoir granites and were overprinted by the contact metamorphic aureole (Figure 3(a)). Aplites and pegmatites derived from the Beauvoir granite also crosscut the $\mathrm{W}$ stockwork (Figures 3(b) and 3(c)). There are two sets of veins, one subparallel and one oblique to the regional foliation, resulting from hydraulic fracturing (Figure 3(d)). Tungsten mineralization is polyphase at the vein scale, since three generations of quartz-ferberite veins have been recognized and emplaced by a crack-and-seal mechanism $[41,42]$. The stockwork was strongly overprinted by the magmatic fluids issued from the Beauvoir granite, resulting in the crystallization of massive topaz ("topazite"), partial replacement of quartz in the veins, 


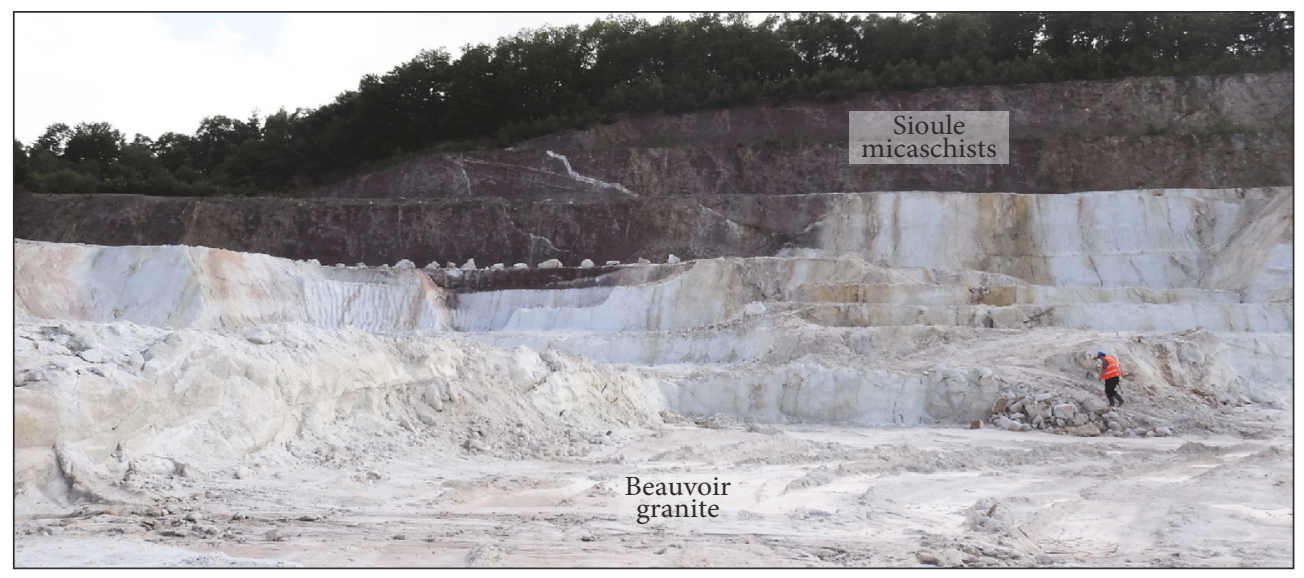

(a)

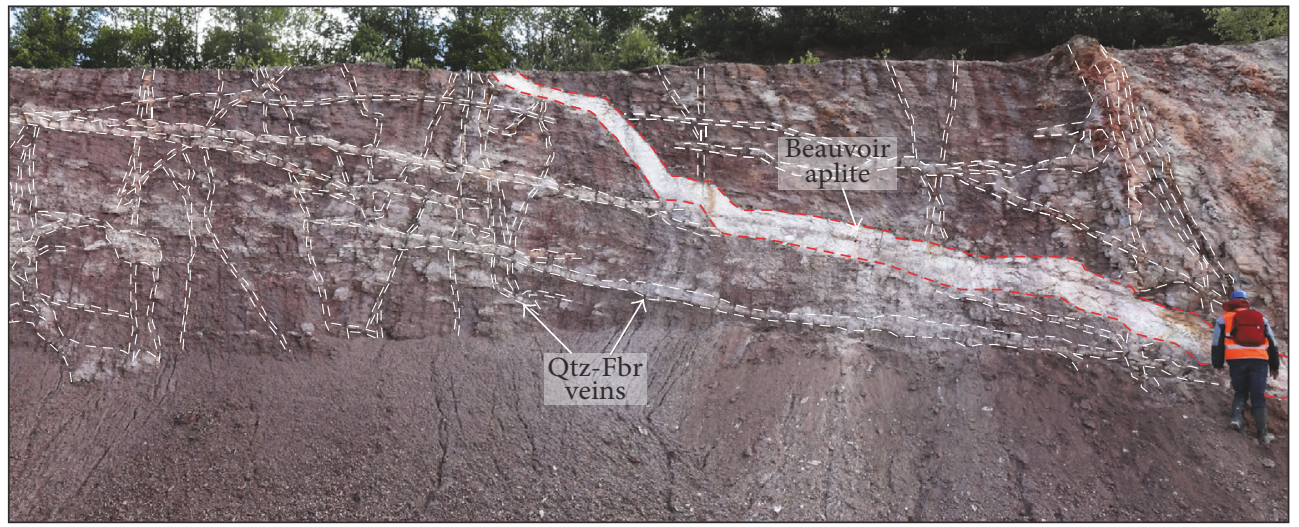

(b)

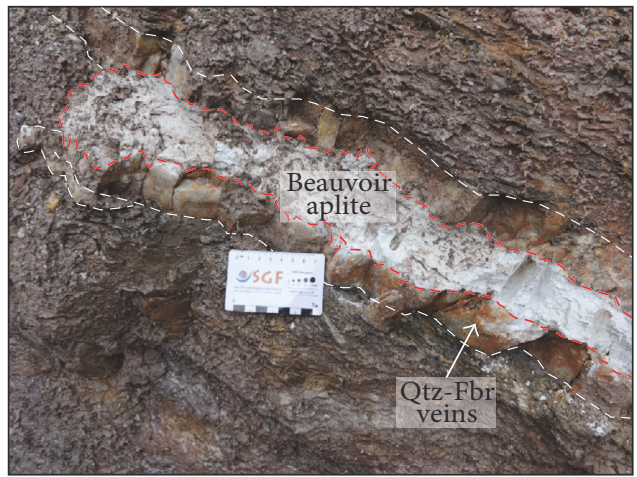

(c)

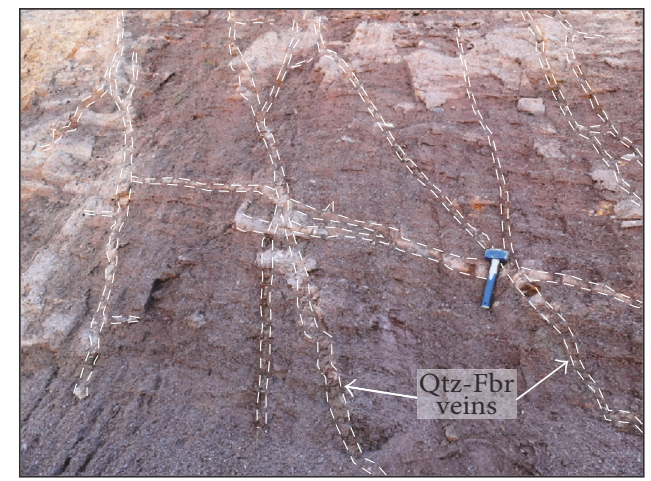

(d)

FiguRE 3: Field photographs of the Beauvoir granite and relationships with the enclosing micaschists. (a) General overview of the upper part of the kaolinized Beauvoir granite intrusive into the Sioule micaschists. (b) Aplite dyke derived from the roof of the Beauvoir granite that crosscut the preexisting quartz- (Qtz-) ferberite (Fbr) veins in the enclosing micaschists. (c) Detailed view of a Beauvoir aplitic dyke reopening an older quartz-ferberite vein. (d) Detailed view of the W stockwork showing the two sets of subparallel and oblique veins that crosscut the micaschists.

and crystallization of late Li-micas and $\mathrm{Nb}-\mathrm{Ta}-\mathrm{W}$ oxides [12]. Ferberite is weakly altered within the topazite, with the formation of dissolution microcavities associated with the sequential crystallization of Ta-rich ferberite, wolframoixiolite, and columbite-tantalite minerals [42]. The development of metasomatic topaz was also observed in the GPF1 drill hole, but only in the upper part of the stockwork located above the roof of the Beauvoir granite $(<-100 \mathrm{~m})$. Indeed, the quartz-ferberite veins in the micaschist enclaves found at the bottom of the drill hole $(>-880 \mathrm{~m})$ were devoid of any topaz [12]. Consequently, the metasomatic alteration appears as a halo located at the top of the $\mathrm{B} 1$ granitic cupola and structurally controlled by the preexisting quartz-ferberite stockwork, thus pointing to a quartz-undersaturated, F- and 
Al-rich fluid and also enriched in rare-metals (W, Nb, Ta, and Li), which was likely derived from the Beauvoir granite.

\subsection{Nature of the Fluid Circulations in the Beauvoir Granite.} Previous works on fluid inclusions in the Beauvoir granite system allowed to reconstruct the P-T-t conditions of fluid circulations and to determine the nature of the different fluid generations [12, 46]. (i) Early magmatic fluids (L1) were only found in topaz from the $\mathrm{B} 1$ facies and correspond to high-temperature $\left(490-590^{\circ} \mathrm{C}\right)$ brines $(25-30 \mathrm{wt} . \% \mathrm{NaCl}$ eq), which are rich in $\mathrm{Li}$ as indicated by low eutectic temperatures $\left(T_{\mathrm{e}}<-65^{\circ} \mathrm{C}\right)$ and direct LIBS measurements (7,500-13,000 ppm Li [29]). The exsolution of this fluid is estimated at ca. $600^{\circ} \mathrm{C}$ and 0.8 kbars. (ii) Boiling of the L1 fluid occurred at high temperature $\left(400-520^{\circ} \mathrm{C}\right)$ after a rapid decompression at $\sim 0.7$ kbars ("first boiling") and yielded by phase separation to a low- to moderate-salinity vapour (V2; 3-12 wt.\% $\mathrm{NaCl}$ eq) and a high-salinity brine (L2; 30-50 wt.\% $\mathrm{NaCl}$ eq). (iii) A low-salinity (2-6 wt.\% $\mathrm{NaCl}$ eq) aqueous fluid (L3) found in the Beauvoir granite was trapped at lower temperature $\left(330-420^{\circ} \mathrm{C}\right)$ and is interpreted from both microthermometric data [46] and stable isotopes data [12] to record the mixing between an external aqueous fluid and the magmatic brine L 2 during the cooling of the granite. (iv) Later circulations involved several generations of aqueous fluids, including low-salinity fluids (L4a; $0-10$ wt.\% $\mathrm{NaCl}$ eq; $120-350^{\circ} \mathrm{C}$ ), moderate-salinity brines (L4b; 20-26 wt.\% $\mathrm{NaCl}$ eq; $200^{\circ} \mathrm{C}$ ), and hypersalinity brines (L4c; 40-60 wt.\% $\mathrm{NaCl}$ eq; $180-225^{\circ} \mathrm{C}$ ). Fluid inclusions found in the topaz replacing the quartz-ferberite veins from the La Bosse stockwork correspond to the same L1, L2, and V2 fluids as in the Beauvoir granite [46]. The early fluid inclusions (L1, L2, and V2) trapped in the primary quartz and topaz from the granite and the stockwork were interpreted as the primary magmatic fluids exsolved from the B1 granite $[12,46]$ and are consequently the main target of the present study.

\section{Materials and Analytical Methods}

3.1. Studied Material. The studied material come from two provenances: (i) two samples of the Beauvoir granite, which were taken from the GPF1 drilling core of the B1 facies at the depths $-125 \mathrm{~m}$ (sample B1-125; Figure 4(a)) and $-379 \mathrm{~m}$ (sample B1-379; Figure 4(b)). These samples allow studying fluid inclusions in the most evolved facies (B1) of the Beauvoir granite located at the top of the granitic cupola, where magmatic fluids are assumed to have been concentrated during the magmatic-hydrothermal transition; (ii) two samples of the metasomatized topaz-quartz-ferberite stockwork, which come from a surface sampling of the old La Bosse quarry, now inaccessible (samples ECH-X2 and ECH-11; Figures 4(c) and 4(d)). These samples allow studying the fluid inclusions in the overprinted vein system and their comparison with those found in the Beauvoir granite. Double-polished thick sections (150-200 $\mu \mathrm{m}$ thick) were prepared for microscopic observations of fluid inclusions in primary quartz and topaz crystals (Figure 5) using an Olympus BX51 optical microscope. Petrographic characterization of fluid inclusions was based on the criteria established by Roedder [47]. All analyses were performed at the GeoRessources laboratory (Université de Lorraine, Vandœuvre-lès-Nancy, France).

3.2. Microthermometry. Microthermometric measurements were realized on a Linkam THMS600 heating-cooling stage connected to an Olympus BX51 microscope. This system allows measurements in a temperature range between $-190^{\circ} \mathrm{C}$ and $600^{\circ} \mathrm{C}$ and is connected to a cooling circuit for measuring temperatures $>300^{\circ} \mathrm{C}$. Calibration was done before each analytical session using $\mathrm{H}_{2} \mathrm{O}$ synthetic capillaries and $\mathrm{H}_{2} \mathrm{O}$ $\mathrm{CO}_{2}$ natural fluid inclusions standards. The accuracy of measurements varies from $\pm 0.2^{\circ} \mathrm{C}$ at low temperature to $\pm 2^{\circ} \mathrm{C}$ at high temperature. The following phase transition temperatures were measured during the microthermometric measurements: the eutectic temperature $\left(T_{\mathrm{e}}\right)$ corresponding to the first visible melting, that is, the apparition of the first visible liquid from the solidified aqueous phase during heating; the ice-melting temperature $\left(T_{\mathrm{m}}\right.$ ice $)$ corresponding to the final melting of solidified aqueous phase; the final melting temperature of hydrohalite $\left(T_{\mathrm{m}} \mathrm{Hh}\right)$; the final melting temperature of halite $\left(T_{\mathrm{m}} \mathrm{Hl}\right)$; and the total homogenization temperature $\left(T_{\mathrm{H}}\right)$, with occur to the liquid phase (L) or to the vapour phase $(\mathrm{V})$. Most of these phase transition temperatures were determined using a heatingcooling cycling method to obtain precise measurements and to avoid metastability effects $[48,49]$. Thick sections of the selected samples were observed under the optical microscope in order to select only fluid inclusions showing petrographic characteristics (content, shape, and size) of the primary fluid inclusions identified by Aïssa et al. [46]. The selected fluid inclusions were firstly investigated at high temperature during microthermometry in order to select only those with $T_{\mathrm{H}}>300^{\circ} \mathrm{C}$, which correspond in principle to the early magmatic fluid inclusions. A progressive stepheating procedure was conducted to limit fracturing of the host-mineral and decrepitation of fluid inclusions. Fluid inclusions were progressively heated with a temperature rate of $30^{\circ} \mathrm{C} / \mathrm{min}$ between room temperature and $200^{\circ} \mathrm{C}$, then $20^{\circ} \mathrm{C} / \mathrm{min}$ for $200^{\circ} \mathrm{C}<\mathrm{T}<400^{\circ} \mathrm{C}$, and finally $10^{\circ} \mathrm{C} / \mathrm{min}$ for $T>400^{\circ} \mathrm{C}$ in order to estimate rapidly the temperature thresholds of the observable phase transitions. Then, the different phase transition temperatures $\left(T_{\mathrm{m}} \mathrm{Hl}, T_{\mathrm{H}}\right)$ were precisely measured with a temperature rate of $1-2^{\circ} \mathrm{C} / \mathrm{min}$ during a second heating cycle. Photographs of fluid inclusions after microthermometric measurements were then compared with the initial pictures before the experiments in order to evaluate any leakage, such as the presence of microcracks or visual variations in shape and/or volume of the vapour phase. The selected fluid inclusions were then analysed during cooling/freezing experiences. Fluid inclusions were firstly overcooled $\left(T<-100^{\circ} \mathrm{C}\right)$ to freeze completely the aqueous and vapour phases and then the temperature of phases transitions $\left(T_{\mathrm{e}}, T_{\mathrm{m}}\right.$ ice, and $\left.T_{\mathrm{m}} \mathrm{Hh}\right)$ were measured while progressively reheating with a temperature rate of $0.2-0.5^{\circ} \mathrm{C} / \mathrm{min}$ typically.

3.3. Raman Spectrometry. Fluid inclusions were analysed by Raman spectrometry using a Horiba Jobin-Yvon LabRAM spectrometer equipped with a $1800 \mathrm{gr} \mathrm{mm}^{-1}$ grating and an 


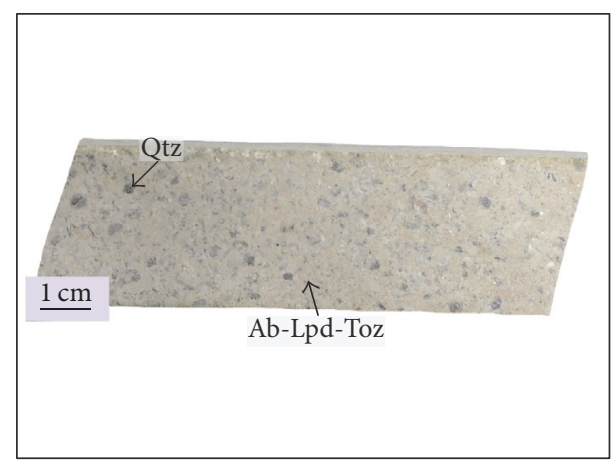

(a) Beauvoir granite (sample B1-125)

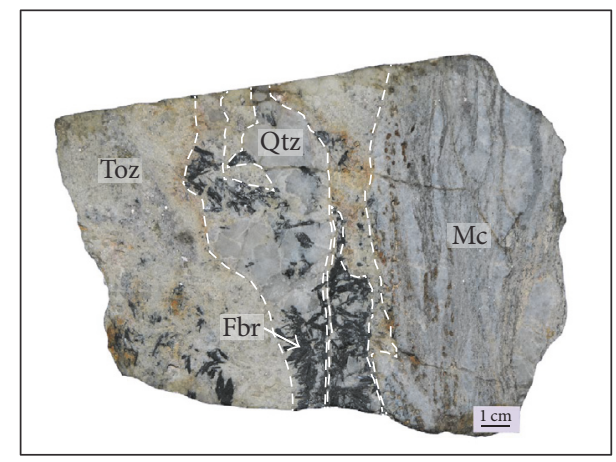

(c) La Bosse stockwork (sample ECH-X2)

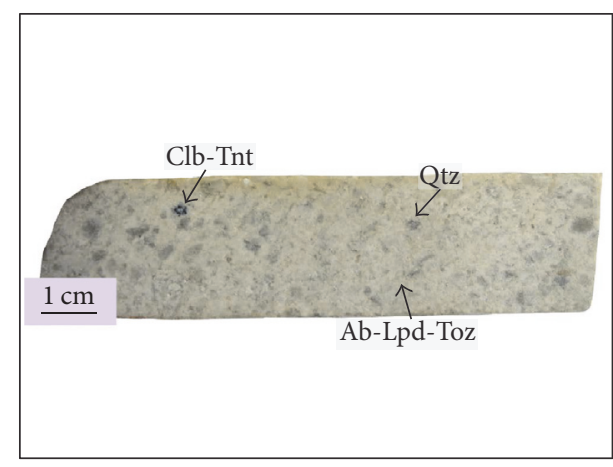

(b) Beauvoir granite (sample B1-379)

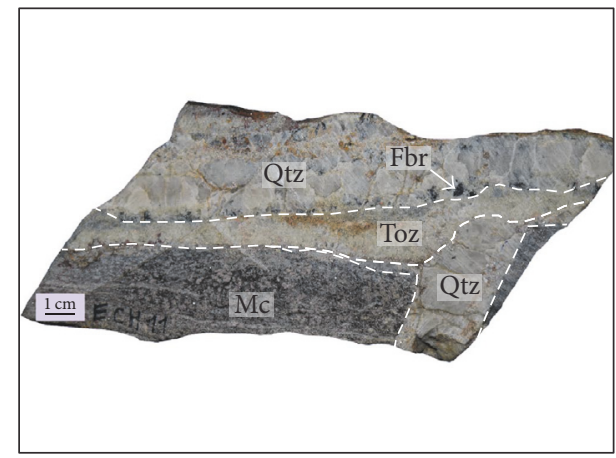

(d) La Bosse stockwork (sample ECH-11)

Figure 4: Photographs of the studied samples from the Beauvoir granite ((a), (b)) and the La Bosse stockwork ((c), (d)). Ab: albite; Clb-Tnt: columbite-tantalite; Fbr: ferberite; Lpd: lepidolite; Mc: micaschist; Qtz: quartz; Toz: topaz.

Edge filter. The confocal hole aperture is of $500 \mu \mathrm{m}$ and the slit aperture is of $100 \mu \mathrm{m}$. The excitation beam is provided by a Stabilite $2017 \mathrm{Ar}^{+}$laser (Spectra Physics, Newport Corporation) at $514.532 \mathrm{~nm}$ and a power of $400 \mathrm{~mW}$, focused on the sample using $\times 50$ and $\times 100$ objectives equipped on an Olympus BX40 microscope. The laser beam diameter is around $1 \mu \mathrm{m}$. The signal-to-noise ratio was optimized ideally lower than $1 \%$ by adjusting the acquisition time and accumulation number. All Raman spectrometry analyses were done at room temperature. Salinity of the aqueous phase in fluid inclusions was estimated by following the method of Caumon et al. [45] and is expressed in wt.\% $\mathrm{NaCl}$ eq. The uncertainty of the measurement is $\pm 0.3 \mathrm{wt} . \% \mathrm{NaCl}$ eq. The quantitative analysis of the gas composing the vapour phase within the fluid inclusions was determined using an in-house calibration. Results are expressed in $\mathrm{mol} \%$ relative to the volatile phase. Finally, solids eventually present within the fluid inclusions were also identified when possible.

3.4. LA-ICPMS Analysis. Chemical composition of the fluid inclusions was determined by laser ablation-inductively coupled plasma mass spectrometry (LA-ICPMS) using an Agilent 7500c quadrupole ICPMS coupled with a $193 \mathrm{~nm}$ GeoLas ArF Excimer laser (MicroLas, Göttingen, Germany). Laser ablation was performed with a constant $10 \mathrm{~Hz}$ pulse frequency and a constant fluence of $7 \mathrm{~J} / \mathrm{cm}^{2}$ by focusing the beam at the sample surface in the ablation cell with a Schwarzschild objective and using a stepwise opening procedure [50], starting the ablation with a laser spot diameter of $2 \mu \mathrm{m}$ and stepwise increasing the spot diameter to the size of the fluid inclusion (from 10 to $80 \mu \mathrm{m}$ ). This procedure allows a controlled ablation by reducing the mechanical stress on the mineral surface, which limits the risk of splashing of the fluid [50]. Helium was used as carrier gas to transport the laser-generated particles from the ablation cell to the ICPMS and argon was added as an auxiliary gas via a flow adapter before the ICP torch. Typical flow rates of $0.5 \mathrm{~L} / \mathrm{min}$ for $\mathrm{He}$ and $0.87 \mathrm{~L} / \mathrm{min}$ for Ar were used. The certified reference material NIST SRM 610 (concentrations from [51]) was used as external standard for calibration of all analyses and was analysed twice at the beginning and at the end for each set of samples, following a bracketing standardization procedure. The reference material NIST SRM 612 was also used as control standard to control the analytical conditions (in particular accuracy and precision). LA-ICPMS calibration was optimized for highest sensitivity on an intermediate $\mathrm{m} / \mathrm{Q}$ range, while maintaining $\mathrm{Th} / \mathrm{U} \sim 1$ and $\mathrm{ThO} / \mathrm{Th}<0.5 \%$, as determined on NIST SRM 610. The following isotopes were measured with a total cycle time of $350 \mathrm{~ms}:{ }^{7} \mathrm{Li},{ }^{23} \mathrm{Na},{ }^{24} \mathrm{Mg}$, ${ }^{29} \mathrm{Si},{ }^{39} \mathrm{~K},{ }^{44} \mathrm{Ca}$, ${ }^{55} \mathrm{Mn}$, and ${ }^{57} \mathrm{Fe}$ with a dwell time of $10 \mathrm{~ms}$; ${ }^{85} \mathrm{Rb}$ and ${ }^{88} \mathrm{Sr}$ with a dwell time of $35 \mathrm{~ms} ;{ }^{93} \mathrm{Nb},{ }^{118} \mathrm{Sn},{ }^{133} \mathrm{Cs}$, ${ }^{181} \mathrm{Ta}$, and ${ }^{182} \mathrm{~W}$ with a dwell time of $40 \mathrm{~ms}$. Data reduction 


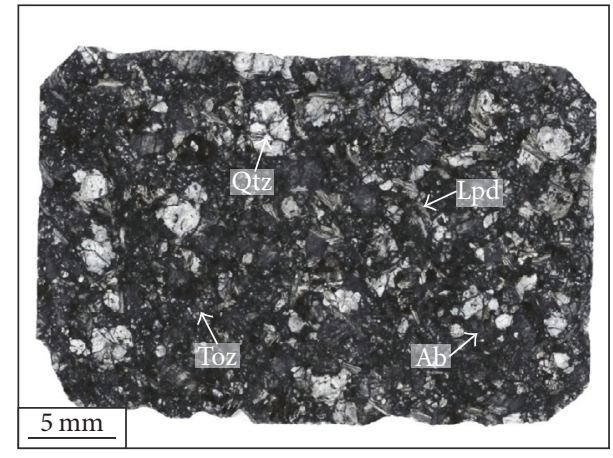

(a) Beauvoir granite (sample B1-125)

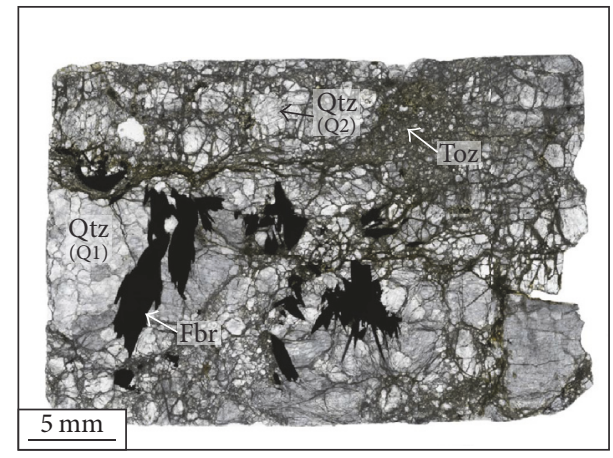

(c) La Bosse stockwork (sample ECH-X2)

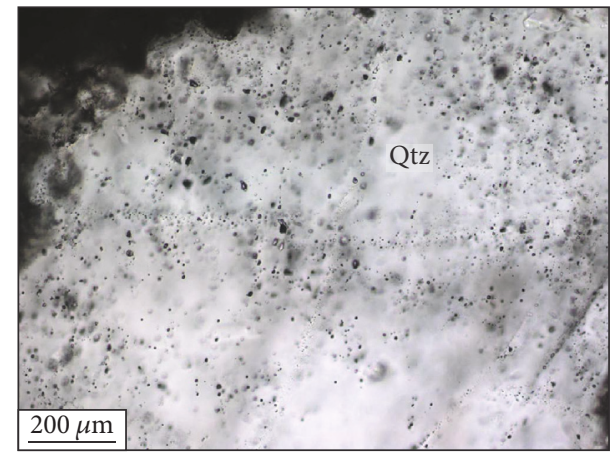

(e) Beauvoir granite (sample B1-125b)

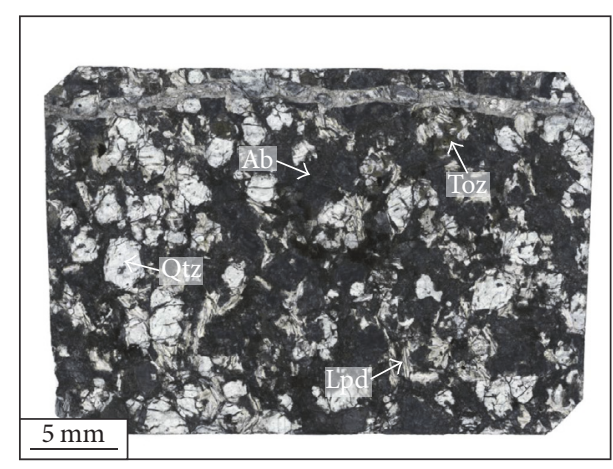

(b) Beauvoir granite (sample B1-379)

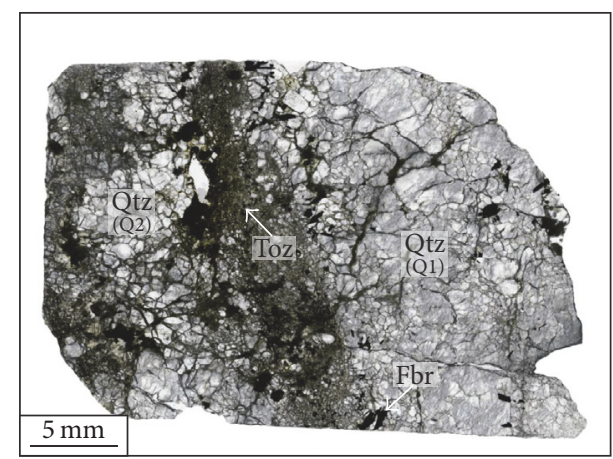

(d) La Bosse stockwork (sample ECH-11)

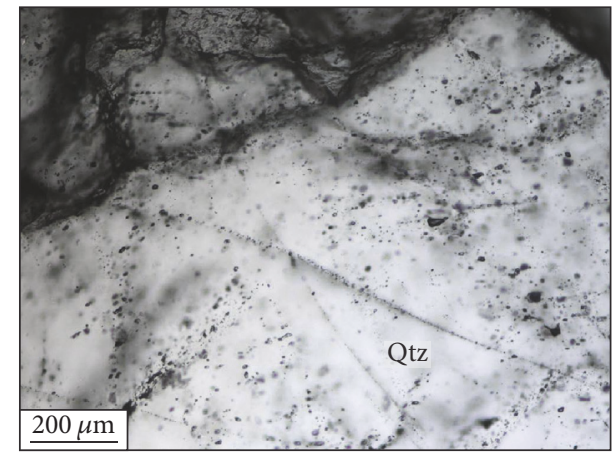

(f) La Bosse stockwork (sample ECH-11a)

FIGURE 5: Photographs of thick sections of the studied samples from the Beauvoir granite ((a), (b)) and the La Bosse stockwork ((c), (d)). Representative microphotographs of fluid inclusions observed in primary quartz from the Beauvoir granite (e) and the La Bosse stockwork (f) are shown. Note the density of disseminated fluid inclusions within the primary quartz and the presence of secondary fluid inclusions planes. Ab: albite; Fbr: ferberite; Lpd: lepidolite; Qtz: quartz; Toz: topaz.

and absolute quantification of signals were performed using the software StalQuant, developed at ETH Zürich, Switzerland (see details in [52]). For all analyses, ${ }^{23} \mathrm{Na}$ was used as internal standard for calculation of absolute concentrations. The molality of $\mathrm{Na}$ (in $\mathrm{mol} / \mathrm{kg}$ ) was calculated from the $\mathrm{NaCl}$ content (in wt.\% eq) of the aqueous phase in fluid inclusions determined by Raman spectrometry when measured and/or from the microthermometric data, following a chargebalancing method to an estimated chloride concentration [53]. Limits of detection (LOD) were calculated using the $2 \sigma$ criterion detailed in Longerich et al. [54].

\section{Results}

4.1. Fluid Inclusion Petrography. Fluid inclusions were described at room temperature under the optical microscope according to their distribution, size, shape, number of visible phases, and volumic fraction of the vapour phase (Rv\%). Four main types of fluid inclusions (L1, L2, V2, and L3) were identified in quartz and topaz crystals from the Beauvoir granite and the La Bosse stockwork by petrographic and microthermometric studies, in accordance with the previous results from Aïssa et al. [46]. The characteristics of the studied fluid inclusions are summarized in Table 1. 


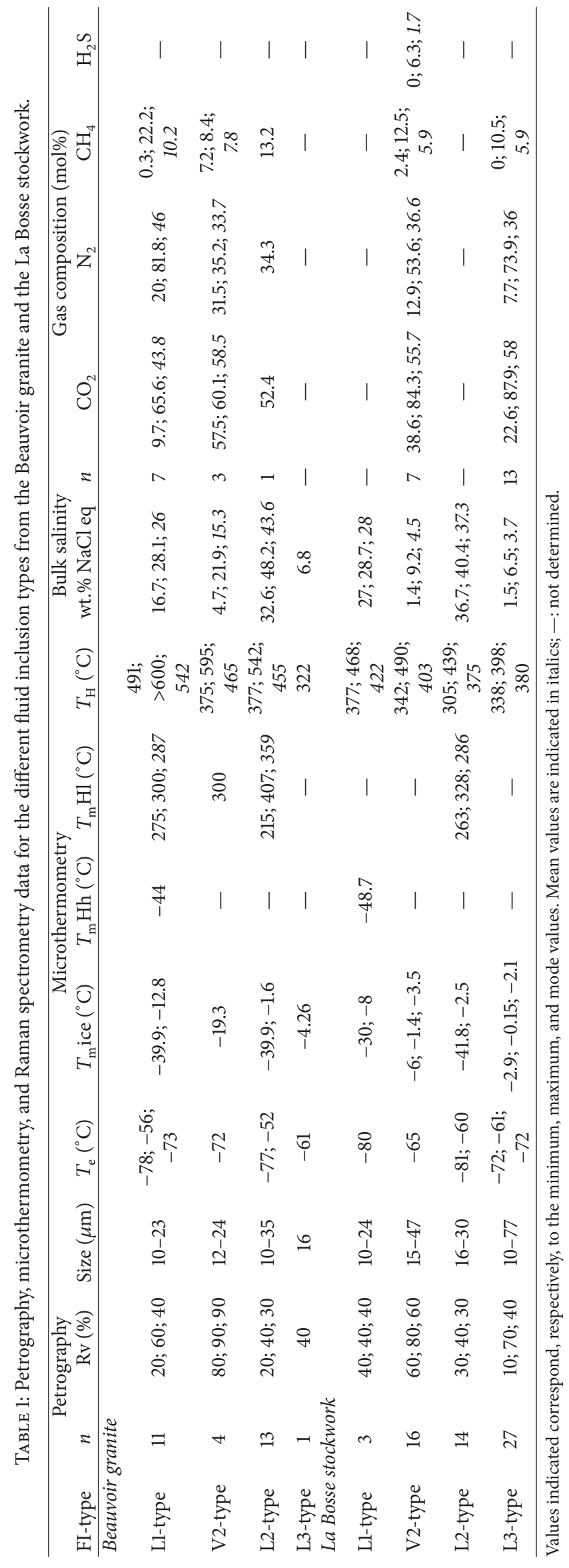




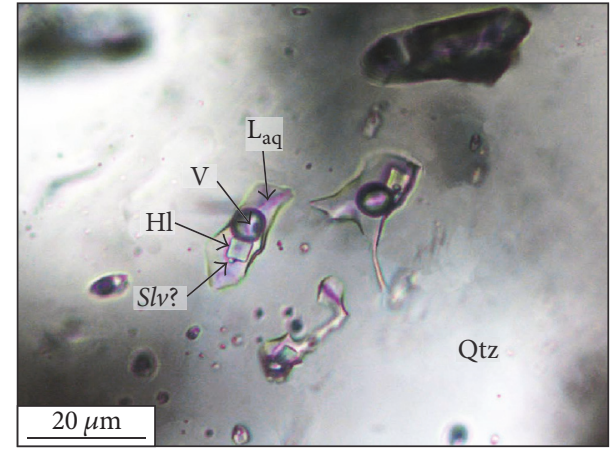

(a) L1-type (sample B1-379a)

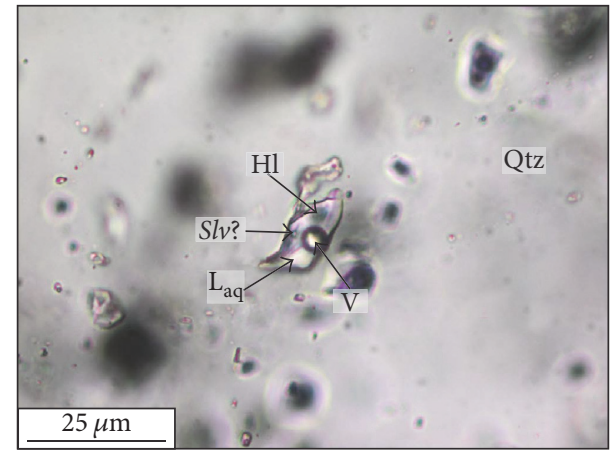

(c) L2-type (sample B1-379a)

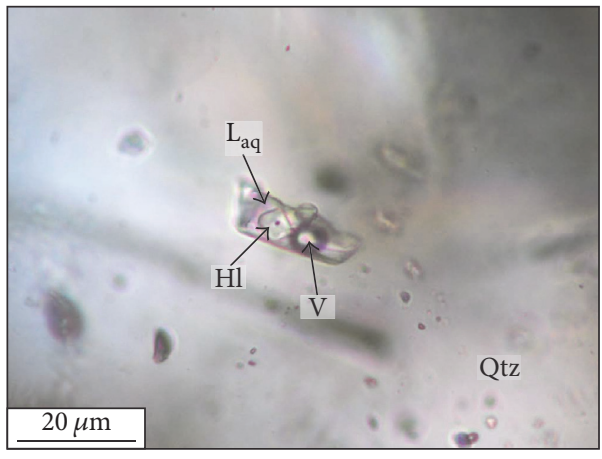

(e) L2-type (sample ECH-X2b)

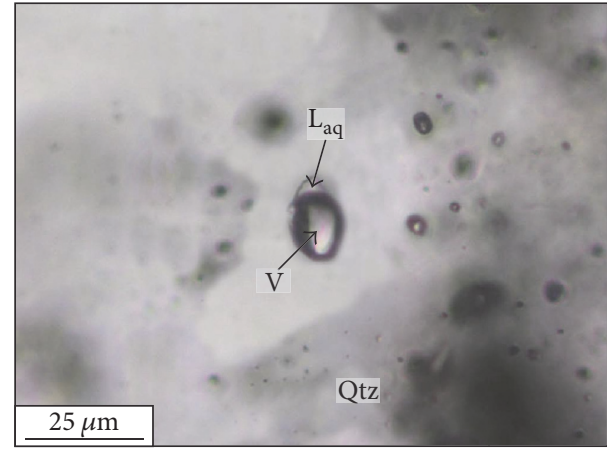

(b) V2-type (sample B1-379a)

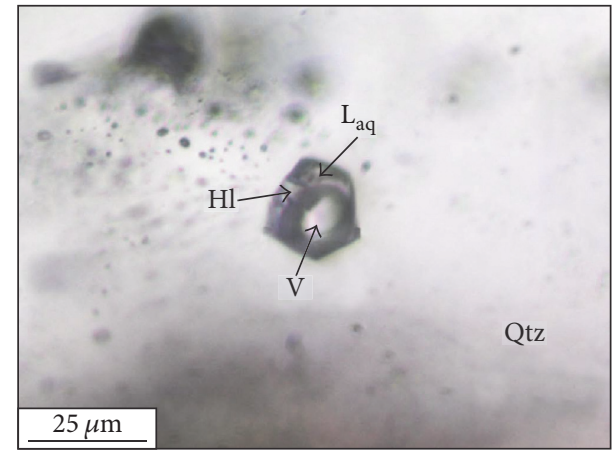

(d) V2-type (sample ECH-11a)

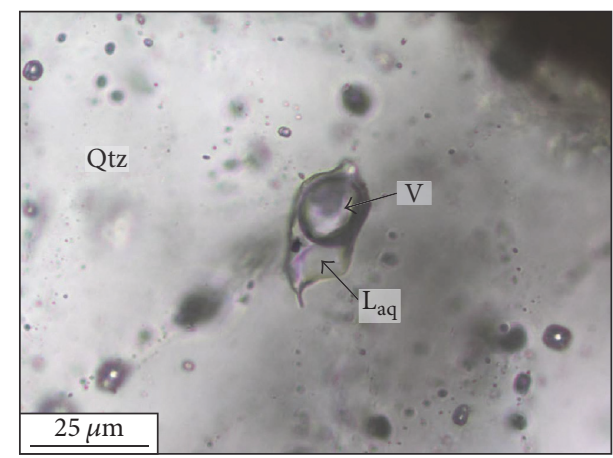

(f) L3 type (sample ECH-X2b)

Figure 6: Microphotographs showing the different types of fluid inclusions. Detailed description of each fluid inclusion type is given in the text. (a) L1-type fluid inclusion in globular quartz crystal from the Beauvoir granite. (b) V2-type fluid inclusion disseminated in globular quartz from the Beauvoir granite. (c) L2-type fluid inclusion from a globular quartz crystal in the Beauvoir granite. (d) V2-type fluid inclusion isolated in the limpid quartz (Q2) from the La Bosse stockwork. (e) L2-type fluid inclusion in limpid quartz (Q2) from the La Bosse stockwork. (f) L3-type fluid inclusion disseminated in limpid quartz (Q2) from the La Bosse stockwork. Hl: halite; $\mathrm{L}_{\mathrm{aq}}$ : liquid aqueous phase; Qtz: quartz; Slv: sylvite; V: vapour phase.

4.1.1. Fluid Inclusions in the Beauvoir Granite. In the Beauvoir granite (facies B1; Figures 5(a) and 5(b)), the quartz forms anhedral to euhedral millimetric globular magmatic crystals, which contain many fluid inclusions. Topaz forms generally limpid subeuhedral crystals disseminated into the granite and contain less fluid inclusions than the quartz. The fluid inclusions in the quartz and topaz crystals form dense clouds of disseminated fluid inclusions or secondary planes (Figure 5(e)). This represents a severe limitation to the identification of the different generations of fluid inclusions based on criteria of relative position or arrangement.
Nevertheless, four main types of fluid inclusions can be distinguished in quartz and topaz based on petrography and microthermometry results.

(i) L1-Type Fluid Inclusions. These are generally found in clusters within the quartz and topaz and have irregular shapes with a size typically ranging from 10 to $23 \mu \mathrm{m}$. These consist of multiphase (liquid + vapour + solid) fluid inclusions at room temperature, with a dominant aqueous phase containing a vapour bubble $(\mathrm{Rv}=40 \%$ on average $)$ and small $(<5 \mu \mathrm{m})$ isotropic solids, including halite and possibly sylvite (Figure 6(a)). 
(ii) V2-Type Fluid Inclusions. These consist of two-phase (liquid + vapour) irregularly shaped inclusions disseminated in clusters, which are independent of the L1 clusters. They contain a dominant vapour phase $(\mathrm{Rv}>80 \%)$ and range approximately from 12 to $24 \mu \mathrm{m}$ in size. Small cubic or rounded crystals of salts (most likely halite) are occasionally observed (Figure 6(b)).

(iii) L2-Type Fluid Inclusions. These are characterized by irregular to regular shapes and have typical sizes comprised between 10 and $35 \mu \mathrm{m}$. They consist of multiphase (liquid + vapour + solid) fluid inclusions, disseminated in clusters in the quartz and topaz. These clusters are independent of the L1 and V2 clusters. The L2-type fluid inclusions contain a dominant aqueous phase and a small vapour phase $(\mathrm{Rv}=$ $30 \%$ on average) and contain several $(n>2)$ crystals of salts, including halite and possibly sylvite (Figure 6(c)).

(iv) L3-Type Fluid Inclusions. They consist of regularly shaped two-phase (liquid + vapour) fluid inclusions of moderate size $(15-20 \mu \mathrm{m})$, which contain a small vapour bubble (Rv $40 \%)$. They are less numerous in the granite and are found as clusters or isolated fluid inclusions, without any clear spatial relationships with the other fluid inclusions types.

4.1.2. Fluid Inclusions in the La Bosse Stockwork. Two types of quartz can be distinguished in the topaz-quartz-ferberiteveins samples from the La Bosse stockwork (Figures 5(c) and 5(d)). Grey quartz (Q1) forms large crystals and contains numerous and small $(<10 \mu \mathrm{m})$ fluid inclusions, either disseminated or forming intragranular planes. The Q1 quartz is deformed and the fluid inclusions appear as black decrepitated or deformed inclusions, probably due to the thermal effect of the Colettes granite emplacement [46]. Based on these observations, Q1 is interpreted as the primary quartz from the quartz-ferberite veins and was not considered in the present study. A limpid quartz (Q2) is also observed that appears as small interstitial crystals or as vein infillings within the altered quartz-ferberite veins. This second generation of quartz is intergrown with topaz and is therefore interpreted as formed by the magmatic fluids from the Beauvoir granite. Fluid inclusions encountered in either Q2 or in topaz are found as disseminated clusters or intragranular planes (Figure 5(f)) and correspond to the same types of fluid inclusions as those found in the granite.

(i) L1-Type Fluid Inclusions. These were found in the Q2 quartz from the stockwork, but not in topaz, being significantly less frequent than in the granite samples. They consist of multiphase (liquid + vapour + halite) fluid inclusions with very irregular shapes, ranging from 10 to $24 \mu \mathrm{m}$ in size.

(ii) V2-Type Fluid Inclusions. They are more frequent in the Q2 quartz and topaz of the stockwork samples than in the Beauvoir granite. They are characterized by regular to slightly irregular shapes with sizes ranging from 15 to $50 \mu \mathrm{m}$ and are always found isolated or in clusters (Figure 6(d)). They contain a dominant vapour phase $(\mathrm{Rv} \sim 60 \%)$ with small $(<5 \mu \mathrm{m})$ greenish elongated isotropic solids observed occasionally and identified as halite. (iii) L2-Type Fluid Inclusions. These have variable sizes (16-30 $\mu \mathrm{m})$ with a dominant aqueous phase and a small vapour bubble ( $\mathrm{Rv} \sim 30 \%$ on average) and contain several $(n=1-3)$ small isotropic solids including halite (Figure 6(e)).

(iv) L3-Type Fluid Inclusions. They are by far the most abundant fluid inclusions within the Q2 quartz and topaz crystals from the stockwork. They consist of two-phase (liquid + vapour) fluid inclusions with a small vapour bubble ( $\mathrm{Rv} \sim$ $20-40 \%$ ), which are irregular to very regular in shape and range from 10 to $77 \mu \mathrm{m}$ in size (Figure 6(f)).

4.2. Microthermometry and Raman Spectrometry Results. Microthermometric and Raman spectrometry data for the different fluid inclusions analysed are given in Table 1 and Figure 7. Despite the use of a careful step-heating procedure, the $T_{\mathrm{H}}$ measurements were strongly limited by the decrepitation of many fluid inclusions (ca. 75\%) before bulk homogenization, which represent therefore a severe limitation for the acquisition of statistics data. The decrepitation temperatures range from 250 to $500^{\circ} \mathrm{C}$ with a mode at ca. $400^{\circ} \mathrm{C}$. Globally, the new results reproduce well the earlier findings of Aïssa et al. [46], including the systematic $\Delta T$ of $\sim 100^{\circ} \mathrm{C}$, which is observed between the $T_{\mathrm{H}}$ measurements in the Beauvoir granite, on the one hand, and in the La Bosse stockwork, on the other hand, for the same type of fluid inclusions.

4.2.1. L1-Type Fluid Inclusions. These are characterized by very low eutectic temperatures $\left(-80^{\circ} \mathrm{C}<T_{\mathrm{e}}<-56^{\circ} \mathrm{C}\right)$ and very low ice-melting temperatures $\left(-39.9^{\circ} \mathrm{C}<T_{\mathrm{m}}\right.$ ice $<-12.8^{\circ} \mathrm{C}$ ). Hydrohalite melting was observed only in two fluid inclusions between -48.7 and $-44^{\circ} \mathrm{C}$. Most of the solids observed within the fluid inclusions correspond to halite crystals. Halite melting occurred in the Beauvoir granite between 275 and $300^{\circ} \mathrm{C}$ before the total homogenization, with an average value of $287^{\circ} \mathrm{C}$. One crystal of cassiterite (ca. $2 \mu \mathrm{m}$ in size) was identified by Raman spectrometry within one fluid inclusion hosted in a topaz crystal from the Beauvoir granite (sample B1-379c, FI n6a; Figure 8) and did not disappear during heating. In the Beauvoir granite, $T_{\mathrm{H}}$ (L) range from 491 to $>600^{\circ} \mathrm{C}$ with an average value of $542^{\circ} \mathrm{C}$. One fluid inclusion in a quartz crystal from the granite was not homogenized at $600^{\circ} \mathrm{C}$, which is the upper limit of the Linkam stage used. Although no clathrate melting was observed in these fluid inclusions, which are mainly aqueous, the vapour phase contains very low-density volatiles, with dominant $\mathrm{CO}_{2}(9.7-65.6 \mathrm{~mol} \%)$ and $\mathrm{N}_{2}(20-82 \mathrm{~mol} \%)$ and minor $\mathrm{CH}_{4}(0.3-22 \mathrm{~mol} \%)$ (Figure 7; Table 1). In the La Bosse stockwork, $T_{\mathrm{H}}(\mathrm{L})$ are lower and range from 377 to $468^{\circ} \mathrm{C}$ with an average value of $422^{\circ} \mathrm{C}$.

4.2.2. V2-Type Fluid Inclusions. These fluid inclusions have very low eutectic temperatures $\left(-72^{\circ} \mathrm{C}<T_{\mathrm{e}}<-65^{\circ} \mathrm{C}\right)$ and low ice-melting temperatures $\left(-19.3^{\circ} \mathrm{C}<T_{\mathrm{m}}\right.$ ice $\left.<-1.4^{\circ} \mathrm{C}\right)$. One $T_{\mathrm{m}} \mathrm{Hl}$ was measured at $300^{\circ} \mathrm{C}$ in a V2 fluid inclusion from the granite, occurring before total homogenization. In the Beauvoir granite, the $T_{\mathrm{H}}(\mathrm{V})$ ranges from 375 to $595^{\circ} \mathrm{C}$ with an average temperature of $465^{\circ} \mathrm{C}$. In the $\mathrm{La}$ Bosse stockwork, they range from 342 to $490^{\circ} \mathrm{C}$ with an 


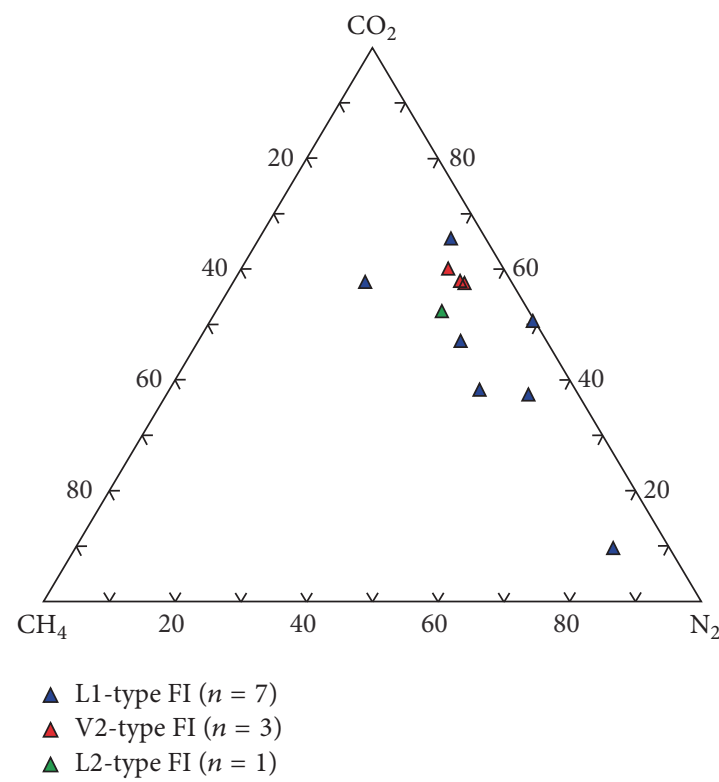

(a) Beauvoir granite

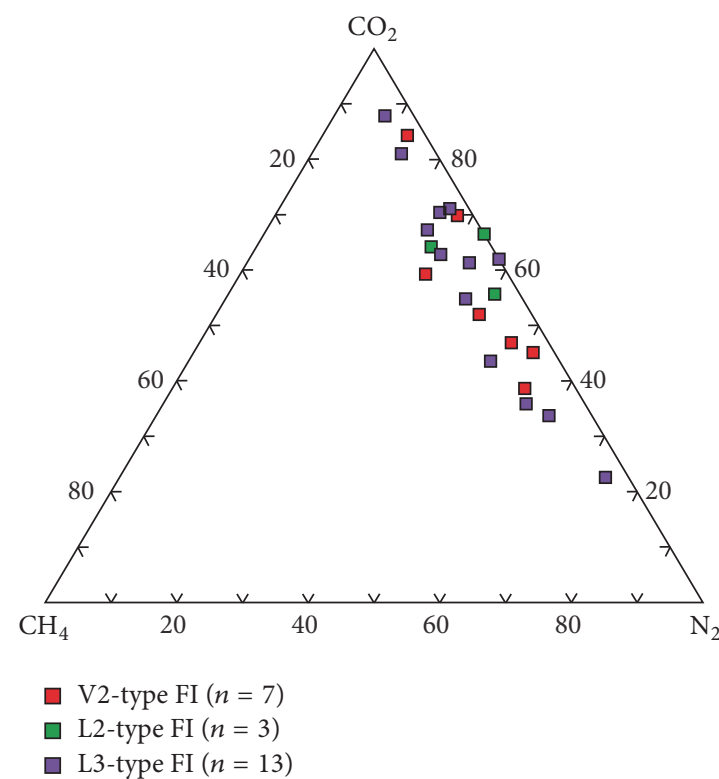

(b) La Bosse stockwork

FIGURE 7: Ternary diagrams $\mathrm{CO}_{2}-\mathrm{CH}_{4}-\mathrm{N}_{2}$ showing the gas compositions of fluid inclusions from the Beauvoir granite (a) and the La Bosse stockwork (b) determined by Raman spectrometry. Representative Raman data of the different fluid inclusions analysed are given in Table 1.

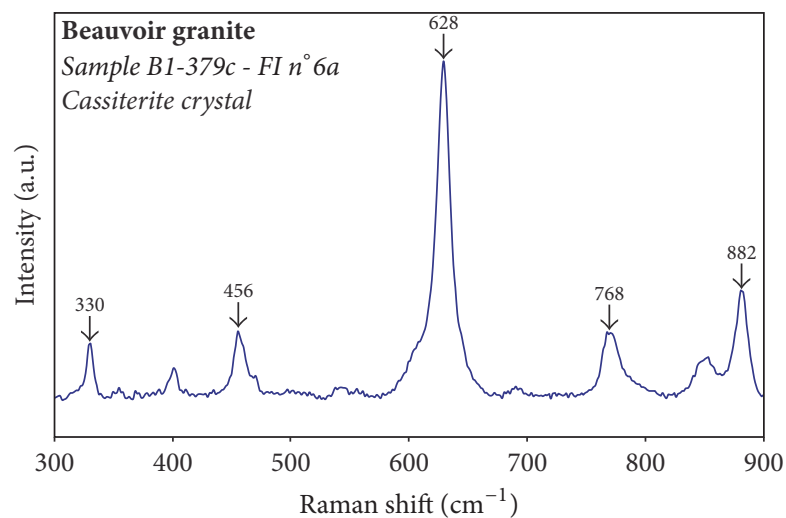

FIGURE 8: Raman spectrum of a cassiterite crystal contained in a primary L1-type fluid inclusion within a magmatic quartz crystal of the Beauvoir granite (sample B1-379c, FI n6a). The Raman shift values indicated on the spectrum correspond to the Raman peaks of cassiterite. The other peaks are those of the host-quartz.

average temperature of $403^{\circ} \mathrm{C}$. Total homogenization occurs mostly to the vapour phase, although a few fluid inclusions $(n=6)$ homogenized in supercritical phase. The vapour phase is dominantly composed by $\mathrm{CO}_{2}(38.6-84.3 \mathrm{~mol} \%), \mathrm{N}_{2}$ (12.9-53.6 mol\%), and minor $\mathrm{CH}_{4}(2.4-12.5 \mathrm{~mol} \%$ ) (Figure 7; Table 1). Minor $\mathrm{H}_{2} \mathrm{~S}$ (1.7 mol\% on average) was detected in V2-type fluid inclusions from the stockwork. These fluid inclusions represent thus low-density fluids, which are composed in majority by vapour $\mathrm{H}_{2} \mathrm{O}$ with trace contents of volatiles compounds $\left(\mathrm{CO}_{2}, \mathrm{~N}_{2}\right.$, and $\left.\mathrm{CH}_{4}\right)$.

4.2.3. L2-Type Fluid Inclusions. These fluid inclusions have very low eutectic temperatures $\left(-81^{\circ} \mathrm{C}<T_{\mathrm{e}}<-52^{\circ} \mathrm{C}\right)$ and very low ice-melting temperatures $\left(-41.8^{\circ} \mathrm{C}<T_{\mathrm{m}}\right.$ ice $<$ $-29^{\circ} \mathrm{C}$ ). Hydrohalite peritectic melting could not be observed in these fluid inclusions. Halite melting occurs systematically before total homogenization with $T_{\mathrm{m}} \mathrm{Hl}$ comprised between 215 and $407^{\circ} \mathrm{C}$, with average values of $359^{\circ} \mathrm{C}$ in the Beauvoir granite and $286^{\circ} \mathrm{C}$ in the La Bosse stockwork. In the Beauvoir granite, $T_{\mathrm{H}}(\mathrm{L})$ ranges from 377 to $542^{\circ} \mathrm{C}$ with an average value of $455^{\circ} \mathrm{C}$, whereas they range from 305 to $439^{\circ} \mathrm{C}$ with an average temperature of $375^{\circ} \mathrm{C}$ in the La Bosse stockwork. No clathrate melting was observed. The vapour phase is composed by $\mathrm{CO}_{2}(52.4-66.5 \mathrm{~mol} \%)$ and $\mathrm{N}_{2}(34.3-40.5 \mathrm{~mol} \%)$, with minor $\mathrm{CH}_{4}$ (9.2-13.2 mol\%) (Figure 7; Table 1).

4.2.4. L3-Type Fluid Inclusions. They have very low eutectic temperatures $\left(-72^{\circ} \mathrm{C}<T_{\mathrm{e}}<-61^{\circ} \mathrm{C}\right)$ and low ice-melting temperatures $\left(-4.3^{\circ} \mathrm{C}<T_{\mathrm{m}}\right.$ ice $\left.<-1.2^{\circ} \mathrm{C}\right) . T_{\mathrm{H}}$ ranges from 338 to $398^{\circ} \mathrm{C}$ with an average temperature of $380^{\circ} \mathrm{C}$ in the La Bosse stockwork. Within the Beauvoir granite, only one $T_{\mathrm{H}}$ of $322^{\circ} \mathrm{C}$ could be measured. The vapour bubble corresponds to a low-density phase composed dominantly by $\mathrm{CO}_{2}$ (22.6-87.9 mol\%) and $\mathrm{N}_{2}$ (7.7-73.9 mol\%), with minor $\mathrm{CH}_{4}$ (0-10.5 mol\%) (Figure 7; Table 1).

4.3. Salinity Calculation. Salinity of the fluid inclusions can be estimated in two ways: (i) from the microthermometric data by knowing the nature of the cations-dominated chemical system, which can be determined by the measurement of $T_{\mathrm{e}}$ and by using experimentally known model systems, such as $\mathrm{H}_{2} \mathrm{O}-\mathrm{NaCl}$ or $\mathrm{H}_{2} \mathrm{O}-\mathrm{NaCl}-\mathrm{CaCl}_{2}$ ([43] and references therein), or (ii) from the Raman spectrometry analysis of the aqueous phase, which allows estimating the chlorinity with a similar precision to the microthermometry [45]. Both methods were used in the present study. The calculation of 


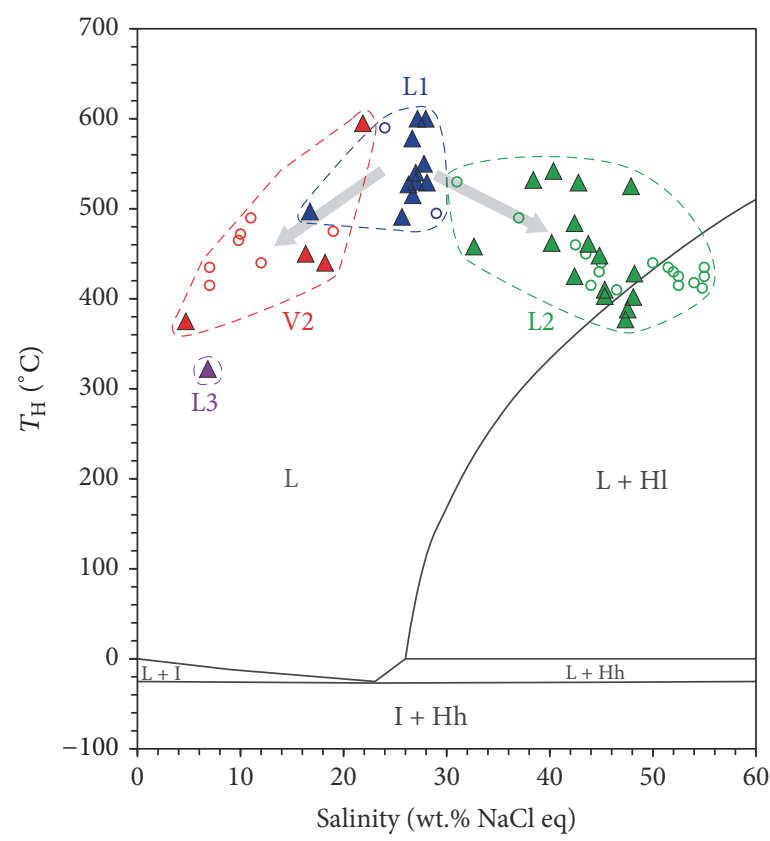

(a) Beauvoir granite

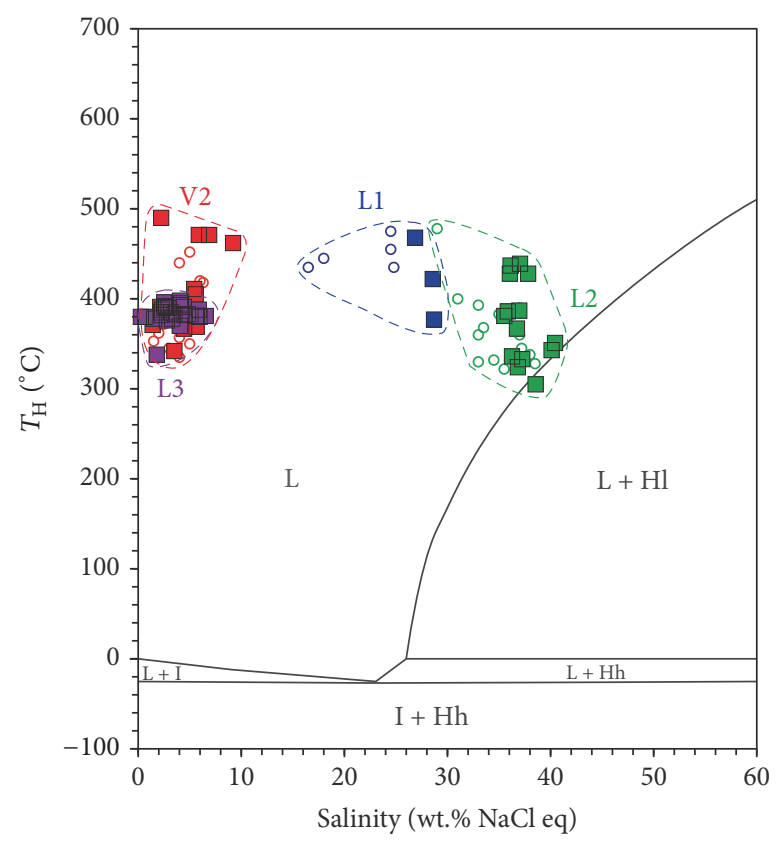

(b) La Bosse stockwork

FIGURE 9: Salinity versus $T_{\mathrm{H}}$ diagram for the different generations of fluid inclusions from the Beauvoir granite (a) and the La Bosse stockwork (b) studied in this work (filled symbols) and compiled with the previous data (open circles) from Aïssa et al. [46]. Data are given in Table 1. Phase equilibrium curves for the pure $\mathrm{H}_{2} \mathrm{O}-\mathrm{NaCl}$ system [43] are reported. $\mathrm{L}=$ liquid; $\mathrm{Hl}=$ halite; $\mathrm{Hh}=$ hydrohalite; $\mathrm{I}=$ ice.

the salinity for the different fluid inclusion types is explained below and a summary of the values is reported in Table 1. Final microthermometric data are shown hereafter in the salinity versus $T_{\mathrm{H}}$ diagram for the Beauvoir granite and the La Bosse stockwork (Figure 9).

\subsubsection{Estimation of the Salinity from the Microthermometric} Data. All the fluid inclusions analysed display very low eutectic temperatures $\left(-80^{\circ} \mathrm{C}<T_{\mathrm{e}}<-60^{\circ} \mathrm{C}\right)$ with a mode value at $-70^{\circ} \mathrm{C}$, which are typical of the $\mathrm{H}_{2} \mathrm{O}-\mathrm{NaCl}$ $\mathrm{LiCl}$ system $[44,55]$. In this system, the bulk salinity and the $\mathrm{Na} / \mathrm{Li}$ ratio of the fluid can be estimated from the $T_{\mathrm{m}}$ ice, $T_{\mathrm{m}} \mathrm{Hh}$, and $T_{\mathrm{m}} \mathrm{Hl}$ measurements [44]. However, the isotherms for temperatures $>100^{\circ} \mathrm{C}$ in the stability field of halite in the $\mathrm{H}_{2} \mathrm{O}-\mathrm{NaCl}-\mathrm{LiCl}$ system are essentially not known at present, hindering in principle these estimations. It is however possible to partly overcome this difficulty by drawing hypothetical isotherms based on the comparison between the existing isotherms in the $\mathrm{H}_{2} \mathrm{O}-\mathrm{NaCl}-\mathrm{LiCl}$ system [44] and those in the $\mathrm{H}_{2} \mathrm{O}-\mathrm{NaCl}-\mathrm{CaCl}_{2}$ system, which are known for temperatures up to $500^{\circ} \mathrm{C}$ ([43] and references therein). The extrapolation of isotherms in the $\mathrm{H}_{2} \mathrm{O}-\mathrm{NaCl}-\mathrm{LiCl}$ diagram from the more known $\mathrm{H}_{2} \mathrm{O}-\mathrm{NaCl}-\mathrm{CaCl}_{2}$ diagram can be justified by the fact that these two thermodynamic systems have very similar invariant points (i.e., eutectic, peritectic; see [44]). This procedure allows estimating both $\mathrm{Na} / \mathrm{Li}$ ratios and bulk salinity and was adopted for the fluid inclusions measured by microthermometry. The extrapolated $\mathrm{H}_{2} \mathrm{O}$ $\mathrm{NaCl}-\mathrm{LiCl}$ ternary diagram is shown on Figure 10 and the

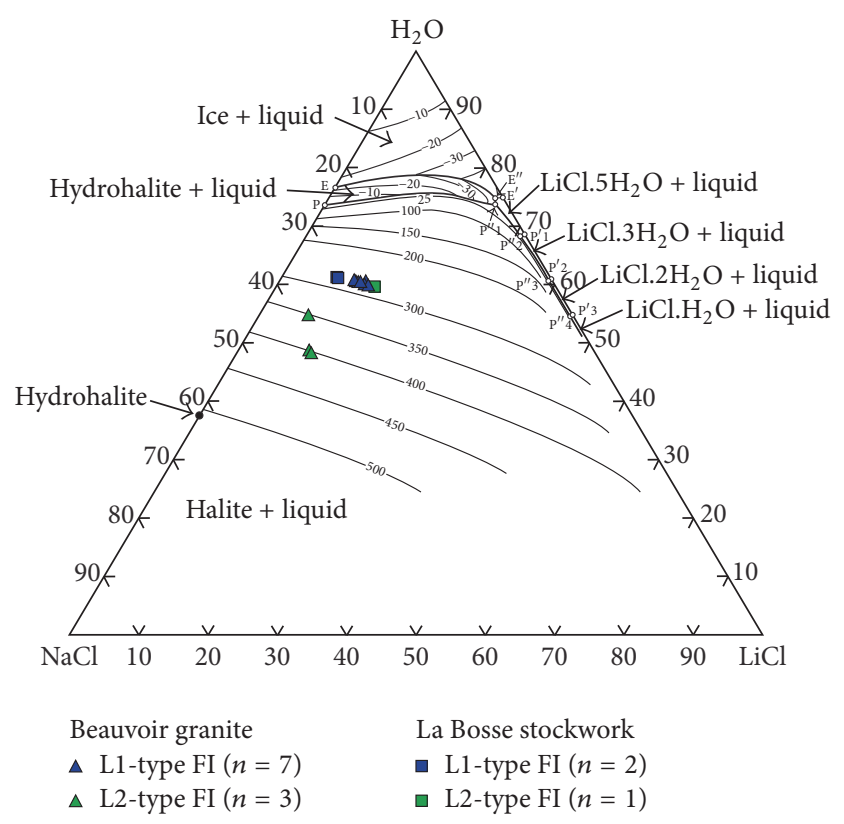

FIGURE 10: Phase diagram of the $\mathrm{H}_{2} \mathrm{O}-\mathrm{NaCl}-\mathrm{LiCl}$ system (after [44]) in which the microthermometric data of the L1- and L2-type fluid inclusions are reported. Concentrations are expressed in wt.\%. E, $\mathrm{E}^{\prime}$, and $\mathrm{E}^{\prime \prime}$ refer to the eutectic points and $\mathrm{P}, \mathrm{P}^{\prime}$, and $\mathrm{P}^{\prime \prime}$ refer to the peritectic points (values given in [44]). Isotherms are given in ${ }^{\circ} \mathrm{C}$ and were extrapolated for $\mathrm{T}>100^{\circ} \mathrm{C}$ in the stability field of halite from the isotherms of the $\mathrm{H}_{2} \mathrm{O}-\mathrm{NaCl}-\mathrm{CaCl}_{2}$ diagram from Bodnar [43] (see explanation in text). Estimations of the bulk salinity and $\mathrm{Na} / \mathrm{Li}$ ratios for the different fluid inclusions are reported in Table 2. 
results are reported in Table 2 and were also compared with the salinity estimates obtained by using the simple $\mathrm{H}_{2} \mathrm{O}-\mathrm{NaCl}$ system [43].

For the L1-type halite-bearing fluid inclusions, the salinity was estimated from the $T_{\mathrm{m}}$ ice and $T_{\mathrm{m}} \mathrm{Hl}$ measurements (Figure 10). Only two $T_{\mathrm{m}} \mathrm{Hl}$ were measured precisely for these fluid inclusions at ca. $280^{\circ} \mathrm{C}$ (Table 2), due to the small size of the fluid inclusions in general $(<15 \mu \mathrm{m}$ on average). Based on the very similar $T_{\mathrm{m}} \mathrm{Hl}$ and considering that the measured $T_{\mathrm{m}} \mathrm{Hh}$ are equivalent, we assumed $T_{\mathrm{m}} \mathrm{Hl}$ value of $280^{\circ} \mathrm{C}$ for the other L1-type fluid inclusions measured, for which the halite disappearance was not clearly observed during heating. Bulk salinity calculated ranges from 24.9 to 28.5 wt. $\% \mathrm{NaCl}$ eq and the $\mathrm{Na} / \mathrm{Li}$ ratios are comprised between 4.6 and 6.5 for the L1-type fluid inclusions from the Beauvoir granite $(n=7)$. In the La Bosse stockwork, bulk salinity is estimated for the L1-type fluid inclusions $(n=2)$ from 30.8 to $31.6 \mathrm{wt} . \%$ $\mathrm{NaCl}$ eq with $\mathrm{Na} / \mathrm{Li}$ ratios $\sim 9$. For the L2-type halite-bearing fluid inclusions, $T_{\mathrm{m}}$ ice and $T_{\mathrm{m}} \mathrm{Hl}$ measurements were also used and reported in the $\mathrm{H}_{2} \mathrm{O}-\mathrm{NaCl}-\mathrm{LiCl}$ ternary diagram (Figure 10). In the Beauvoir granite, the $T_{\mathrm{m}} \mathrm{Hl}$ for the L2-type fluid inclusions are higher compared to those of the L1-type ones ranging from 354 to $406^{\circ} \mathrm{C}$. Bulk salinity determined for L2-type fluid inclusions in the Beauvoir granite $(n=3)$ ranges from 37.8 to 41.9 wt.\% $\mathrm{NaCl}$ eq with $\mathrm{Na} / \mathrm{Li}$ ratios comprised between 9 and 12.6. For the La Bosse stockwork, one L2-type fluid inclusion is characterized by bulk salinity of $25.6 \mathrm{wt} . \%$ $\mathrm{NaCl}$ eq with a $\mathrm{Na} / \mathrm{Li}$ ratio of 4.3. A rough estimation by simply using the $\mathrm{H}_{2} \mathrm{O}-\mathrm{NaCl}$ system [43] yields to salinity in the range of $31.9-36.8$ and $42.8-48.1 \mathrm{wt} . \% \mathrm{NaCl}$ eq for the L1- and L2-types fluid inclusions in the Beauvoir granite, respectively (Table 2 ), which seems overestimated.

Finally, for the two-phase (liquid + vapour) V2- and L3-types fluid inclusions, estimation of the salinity in the $\mathrm{H}_{2} \mathrm{O}-\mathrm{NaCl}-\mathrm{LiCl}$ system requires the measurements of the $T_{\mathrm{m}}$ ice and $T_{\mathrm{m}} \mathrm{Hh}$. However, it was not possible to observe the hydrohalite melting in these fluid inclusions, principally because of their small size ( $<15 \mu \mathrm{m}$ on average), and therefore the salinity cannot be estimated directly in the $\mathrm{H}_{2} \mathrm{O}-\mathrm{NaCl}-$ $\mathrm{LiCl}$ system and was only estimated by Raman spectrometry when measured (see below) or calculated in the $\mathrm{H}_{2} \mathrm{O}-\mathrm{NaCl}$ system based on the $T_{\mathrm{m}}$ ice measurement, as the best possible approximation. The $\mathrm{Na} / \mathrm{Li}$ ratios for the V2- and L3-types fluid inclusions were calculated from the LA-ICPMS analyses only.

4.3.2. Estimation of the Salinity from the Raman Spectrometry Data. Considering the problem of $T_{\mathrm{m}} \mathrm{Hl}$ and $T_{\mathrm{m}} \mathrm{Hh}$ measurements, the Raman spectrometry represents an interesting alternative to estimate the bulk salinity of the fluid inclusions with a fast, systematic, and reproducible acquisition with accuracy better than $\pm 10 \%$ on average [45]. The method developed by Caumon et al. [45] has been calibrated only for $\mathrm{NaCl}$ solutions, which may possibly lead to a bias in the salinity estimation of LiCl-rich fluid inclusions due to the deformation of the stretching band of water induced by Li. Nevertheless, previous study by Dubessy et al. [56] has shown that the Raman calibration curve for $\mathrm{LiCl}$ solutions is similar to the one of $\mathrm{CaCl}_{2}$, both differing slightly from the calibration curve of $\mathrm{NaCl}$. Consequently, the salinity of the aqueous phase in fluid inclusions estimated by following the method of Caumon et al. [45] can be considered as a good approximation of the bulk salinity in the case of $\mathrm{H}_{2} \mathrm{O}-\mathrm{NaCl}$ $\mathrm{LiCl}$ solutions. Salinity calculated by Raman spectrometry is reported in Table 3.

The estimated salinity for the L1-type fluid inclusions in the Beauvoir granite ranges from 25.7 to $28.1 \mathrm{wt} . \% \mathrm{NaCl}$ eq, with an average of $27 \mathrm{wt} . \% \mathrm{NaCl}$ eq $(n=7)$. One L1-type fluid inclusion from the La Bosse stockwork was measured by Raman spectrometry and yielded to a bulk salinity of 27 wt.\% $\mathrm{NaCl}$ eq. The calculated salinity for the V2-type fluid inclusions ranges from 4.7 to $18.2 \mathrm{wt} \% \mathrm{NaCl}$ eq in the Beauvoir granite, with an average value of $13.1 \mathrm{wt} . \%$ $\mathrm{NaCl}$ eq $(n=3)$, and from 1.4 to 6.9 wt. $\% \mathrm{NaCl}$ eq in the La Bosse stockwork, with an average value of 3.9 wt.\% $\mathrm{NaCl}$ eq $(n=6)$. The Raman salinity was determined for one L2-type fluid inclusion in the La Bosse stockwork with a value of $37.6 \mathrm{wt}$ \% $\mathrm{NaCl}$ eq. Salinity for L3-type fluid inclusions in the La Bosse stockwork ranges from 2.3 to 6.6 wt. $\% \mathrm{NaCl}$ eq with an average value of 4.8 wt. $\% \mathrm{NaCl}$ eq $(n=10)$.

4.3.3. Synthesis: Bulk Salinity of the Fluid Inclusions. In conclusion, the salinity determined by Raman spectrometry is in good agreement with the one determined in the $\mathrm{H}_{2} \mathrm{O}$ $\mathrm{NaCl}-\mathrm{LiCl}$ system, whereas the salinity determined in the $\mathrm{H}_{2} \mathrm{O}-\mathrm{NaCl}$ system appears overestimated in comparison with the two other calculated salinities. Therefore, the salinity determined by Raman spectrometry was used when measured, and if not, the salinity determined using the $\mathrm{H}_{2} \mathrm{O}$ $\mathrm{NaCl}-\mathrm{LiCl}$ system was chosen. The final bulk salinity of the different type of fluid inclusions is shown in Table 1 and summarized below.

(i) L1-Type Fluid Inclusions. They have salinity comprised between 16.7 and 28.1 wt.\% $\mathrm{NaCl}$ eq in the Beauvoir granite, with an average value of 26 wt. $\% \mathrm{NaCl}$ eq, and between 27 and 28.7 wt. $\% \mathrm{NaCl}$ eq in the La Bosse stockwork, with an average value of 28 wt. $\% \mathrm{NaCl}$ eq.

(ii) V2-Type Fluid Inclusions. These have salinity ranging from 4.7 to 21.9 wt.\% $\mathrm{NaCl}$ eq with an average value of $15.3 \mathrm{wt} . \%$ $\mathrm{NaCl}$ eq in the Beauvoir granite and from 1.4 to $9.2 \mathrm{wt} . \%$ $\mathrm{NaCl}$ eq in the La Bosse stockwork, with an average salinity of 4.5 wt. $\% \mathrm{NaCl}$ eq.

(iii) L2-Type Fluid Inclusions. They are characterized by the highest salinities comprised between 32.6 and $48.2 \mathrm{wt} \% \mathrm{NaCl}$ eq in the Beauvoir granite, with an average of $43.6 \mathrm{wt} \% \mathrm{NaCl}$ eq, and between 36.7 and 40.4 wt.\% NaCl eq in the La Bosse stockwork, with an average value of 37.3 wt. $\% \mathrm{NaCl}$ eq.

(iv) L3-Type Fluid Inclusions. These have the lowest salinities in all the studied fluid inclusions. The only L3-type fluid inclusion analysed in the Beauvoir granite has a salinity of 6.8 wt. $\% \mathrm{NaCl}$ eq, whereas they range from 1.5 to $6.5 \mathrm{wt} . \%$ $\mathrm{NaCl}$ eq in the La Bosse stockwork, with an average value of 3.7 wt. $\% \mathrm{NaCl}$ eq. 


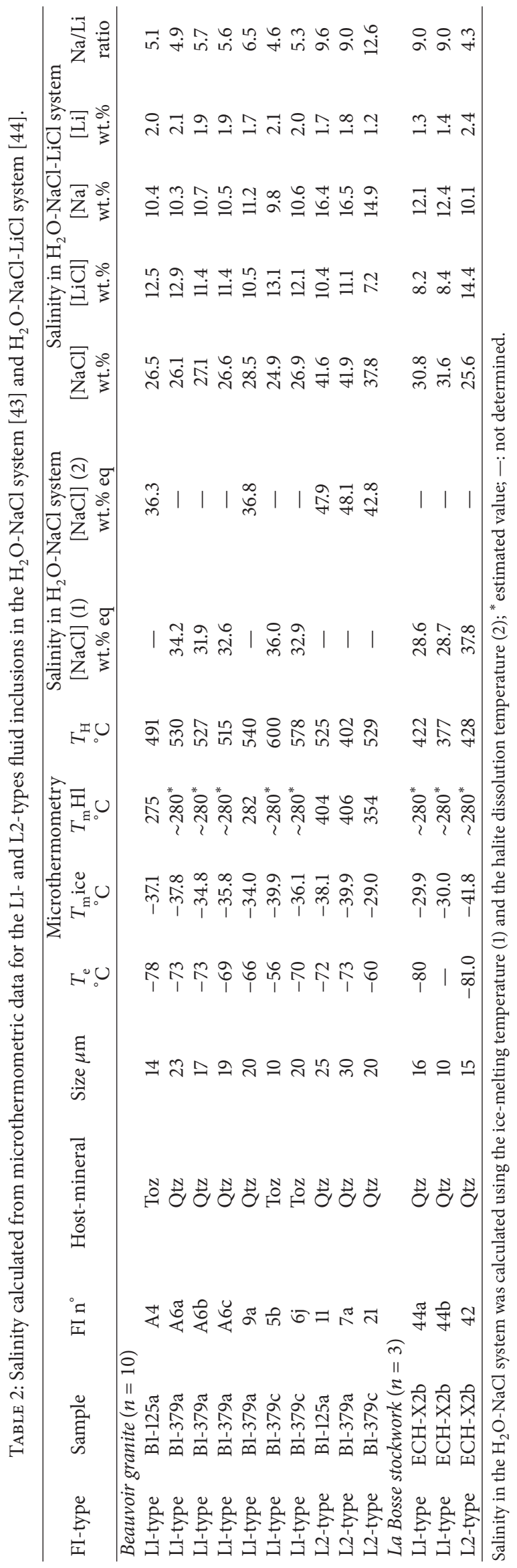


4.4. LA-ICPMS Analysis of Fluid Inclusions. The different generations of fluid inclusions were analysed by LA-ICPMS, with a focus onto the L1-, L2-, and V2-types, which are interpreted as the earliest fluids exsolved from the Beauvoir granite. The quality of the signals measured by LA-ICPMS depends highly of the size and of the depth of the fluid inclusions in the two ablated minerals (quartz and topaz). A typical LA-ICPMS spectrum of L1-type fluid inclusion from the Beauvoir granite is shown in Figure 11. The fluid inclusion signal is ca. $24 \mathrm{~s}$ in length and shows relatively high signal intensities $\left(10^{1}-10^{4} \mathrm{cps}\right)$ for most of the elements measured ( $\mathrm{Sn}, \mathrm{Cs}, \mathrm{Nb}, \mathrm{Ta}, \mathrm{W}, \mathrm{Rb}$, and $\mathrm{Li}$ ). The $\mathrm{Na}$ signal is low due to the relatively high analytical background ( 2,000 cps; LOD $\sim 5,300 \mathrm{ppm}$ ) of the instrument, which represents a technical limitation for the absolute quantification of the fluid inclusion signals. However, analytical background is generally low $(<10$ cps) for the other measured elements, excepted for $\mathrm{K}(\sim 250$ cps; LOD 1,700 ppm), Ca ( 100 cps; LOD 3,000 ppm), and Mn ( $\sim 60$ cps; LOD 250 ppm). On the 47 fluid inclusions analysed by LA-ICPMS, only 27 yielded interpretable signals and were selected for absolute quantification. The salinity calculated (Table 1) was used to estimate the Na content of the fluid inclusions analysed and used as internal standard for the quantification of the fluid inclusions signals.

Results of LA-ICPMS analysis are given in Table 4 and shown in Figure 12. A discrepancy can be observed between the $\mathrm{Na} / \mathrm{Li}$ ratios calculated from the microthermometric data and the LA-ICPMS data. Indeed, the $\mathrm{Na} / \mathrm{Li}$ ratios estimated from microthermometry in the $\mathrm{H}_{2} \mathrm{O}-\mathrm{NaCl}-\mathrm{LiCl}$ system fall in the range 4.3-12.6 (Table 2), whereas those calculated from the LA-ICPMS data are significantly higher and comprised between 0.9 and 33 (Table 4). The latter are not consistent with (i) the very low eutectic temperatures $\left(T_{\mathrm{e}}<-70^{\circ} \mathrm{C}\right)$ indicating that the magmatic fluid was Li-rich and (ii) preliminary LIBS analysis on primary L1-type fluid inclusions from the Beauvoir granite, which yielded $\mathrm{Na} / \mathrm{Li}$ ratios comprised between 1.1 and 2.7 [29]. Therefore, it seems that the Li content is underestimated by LA-ICPMS, thus resulting in higher $\mathrm{Na} / \mathrm{Li}$ ratios.

\subsubsection{Fluid Inclusions in the Beauvoir Granite}

L1-Type Fluid Inclusions $(n=5)$. They are characterized by very high contents in $\mathrm{Na}(103,500-110,600 \mathrm{ppm})$, Sn (1,170-38,450 ppm), Cs (22,200-75,650 ppm), K (32,300$41,720 \mathrm{ppm})$, high contents in $\mathrm{Mn}(8,930-29,300 \mathrm{ppm})$, Fe (12,550-16,800 ppm), Rb (1,380-9,330 ppm), Li (4,450$17,960 \mathrm{ppm})$, and $\mathrm{W}(920-2,970 \mathrm{ppm})$ and minor contents in $\mathrm{Nb}(36-1,450 \mathrm{ppm}), \mathrm{Ta}(18-180 \mathrm{ppm})$, and $\mathrm{Sr}$ (16-130 ppm). Their $\mathrm{Na} / \mathrm{Li}$ and $\mathrm{Na} / \mathrm{K}$ ratios range from 6.2 to 24 and from 2.5 to 4.6 , respectively.

V2-Type Fluid Inclusions $(n=2)$. They have lower concentrations in most of the measured elements compared to the L1-type fluid inclusions and also among all the analysed fluid inclusions in the Beauvoir granite. They are characterized by relatively high contents in $\mathrm{Na}(71,600-$ $86,200 \mathrm{ppm})$, Li (25,440-28,480 ppm), K (33,850-46,200 ppm), Cs (19,100-21,600 ppm), Mn (2,640-22,400 ppm), and
TABLE 3: Salinity estimated from Raman spectrometry data for fluid inclusions analysed using the method of Caumon et al. [45].

\begin{tabular}{|c|c|c|c|c|c|}
\hline FI-type & Sample & $\mathrm{FI} \mathrm{n}^{\circ}$ & $\begin{array}{l}\text { Host- } \\
\text { mineral }\end{array}$ & $\begin{array}{l}\text { Size } \\
\mu \mathrm{m}\end{array}$ & $\begin{array}{c}\text { [NaCl] } \\
\text { wt. } \% \\
\text { eq }\end{array}$ \\
\hline \multicolumn{6}{|c|}{ Beauvoir granite $(n=10)$} \\
\hline L1-type & B1-125a & A4 & Toz & 14 & 25.7 \\
\hline L1-type & B1-125a & B1 & Qtz & 16 & 27.2 \\
\hline L1-type & B1-379a & A6a & Qtz & 23 & 27.0 \\
\hline L1-type & B1-379a & $\mathrm{A} 6 \mathrm{~b}$ & Qtz & 17 & 26.3 \\
\hline L1-type & B1-379a & A6c & Qtz & 19 & 26.7 \\
\hline L1-type & B1-379c & $\mathrm{Cl}$ & Qtz & 14 & 28.1 \\
\hline L1-type & B1-379a & $9 b$ & Qtz & 15 & 27.8 \\
\hline V2-type & B1-379a & A10a & Qtz & 14 & 18.2 \\
\hline V2-type & B1-379a & $\mathrm{A} 10 \mathrm{c}$ & Qtz & 18 & 16.3 \\
\hline V2-type & B1-379a & B4 & Qtz & 12 & 4.7 \\
\hline \multicolumn{6}{|c|}{ La Bosse stockwork $(n=18)$} \\
\hline L1-type & $\mathrm{ECH}-\mathrm{X} 2 \mathrm{~b}$ & 6 & Qtz & 24 & 27 \\
\hline V2-type & $\mathrm{ECH}-\mathrm{X} 2 \mathrm{~b}$ & D4 & Qtz & 42 & 6.9 \\
\hline V2-type & ECH-11a & D4 & Qtz & 15 & 4.1 \\
\hline V2-type & ECH-11a & D2 & Qtz & 18 & 2.2 \\
\hline V2-type & ECH-1lb & D2 & Toz & 47 & 2.1 \\
\hline V2-type & ECH-11b & la & Qtz & 20 & 1.1 \\
\hline V2-type & ECH-11b & $2 \mathrm{a}$ & Qtz & 45 & 4.4 \\
\hline L2-type & $\mathrm{ECH}-\mathrm{X} 2 \mathrm{~b}$ & B2 & Toz & 16 & 37.6 \\
\hline L3-type & $\mathrm{ECH}-\mathrm{X} 2 \mathrm{~b}$ & $\mathrm{~A} 1$ & Qtz & 11 & 4.4 \\
\hline L3-type & $\mathrm{ECH}-\mathrm{X} 2 \mathrm{~b}$ & $\mathrm{~A} 3$ & Qtz & 20 & 6.0 \\
\hline L3-type & $\mathrm{ECH}-\mathrm{X} 2 \mathrm{~b}$ & $\mathrm{~A} 4$ & Qtz & 77 & 4.5 \\
\hline L3-type & $\mathrm{ECH}-\mathrm{X} 2 \mathrm{~b}$ & B3 & Qtz & 27 & 5.9 \\
\hline L3-type & $\mathrm{ECH}-\mathrm{X} 2 \mathrm{~b}$ & $\mathrm{C} 3 \mathrm{a}$ & Qtz & 35 & 5.7 \\
\hline L3-type & $\mathrm{ECH}-\mathrm{X} 2 \mathrm{~b}$ & $\mathrm{C} 3 \mathrm{~b}$ & Qtz & 32 & 5.6 \\
\hline L3-type & $\mathrm{ECH}-\mathrm{X} 2 \mathrm{c}$ & $9 a$ & Toz & 10 & 3.3 \\
\hline L3-type & $\mathrm{ECH}-\mathrm{X} 2 \mathrm{c}$ & $9 b$ & Toz & 25 & 3.5 \\
\hline L3-type & ECH-11b & $3 a$ & Qtz & 10 & 2.3 \\
\hline L3-type & ECH-11b & A6 & $\mathrm{Toz}$ & 45 & 6.6 \\
\hline
\end{tabular}

Rb (7,360-11,100 ppm) and moderate contents in Sn (1,100$4,270 \mathrm{ppm})$ and $\mathrm{W}$ (250-550 ppm), yielding to ratios $\mathrm{Na} / \mathrm{Li} \sim$ 3 and $\mathrm{Na} / \mathrm{K} \sim 2$.

L2-Type Fluid Inclusions $(n=6)$. They have among the highest concentrations of the fluid inclusions analysed. They have very high contents in $\mathrm{Na}(158,200-189,700 \mathrm{ppm}), \mathrm{K}$ (65,350-128,000 ppm), Cs (23,700-42,150 ppm), Sn (14,300$75,000 \mathrm{ppm})$, and $\mathrm{Mn}(44,550-86,500 \mathrm{ppm})$, high contents in $\mathrm{Li}(7,370-51,310 \mathrm{ppm})$, Fe (22,000-41,800 ppm), and Rb (14,950-44,100 ppm), and relatively high contents in $\mathrm{W}$ (1,230-4,250 ppm), Sr (32-84 ppm), Nb (11-1,590 ppm), and $\mathrm{Ta}(2-2,280 \mathrm{ppm})$. The $\mathrm{Na} / \mathrm{Li}$ and $\mathrm{Na} / \mathrm{K}$ ratios range from 3 to 23 and from 1.5 to 2.6 , respectively. 


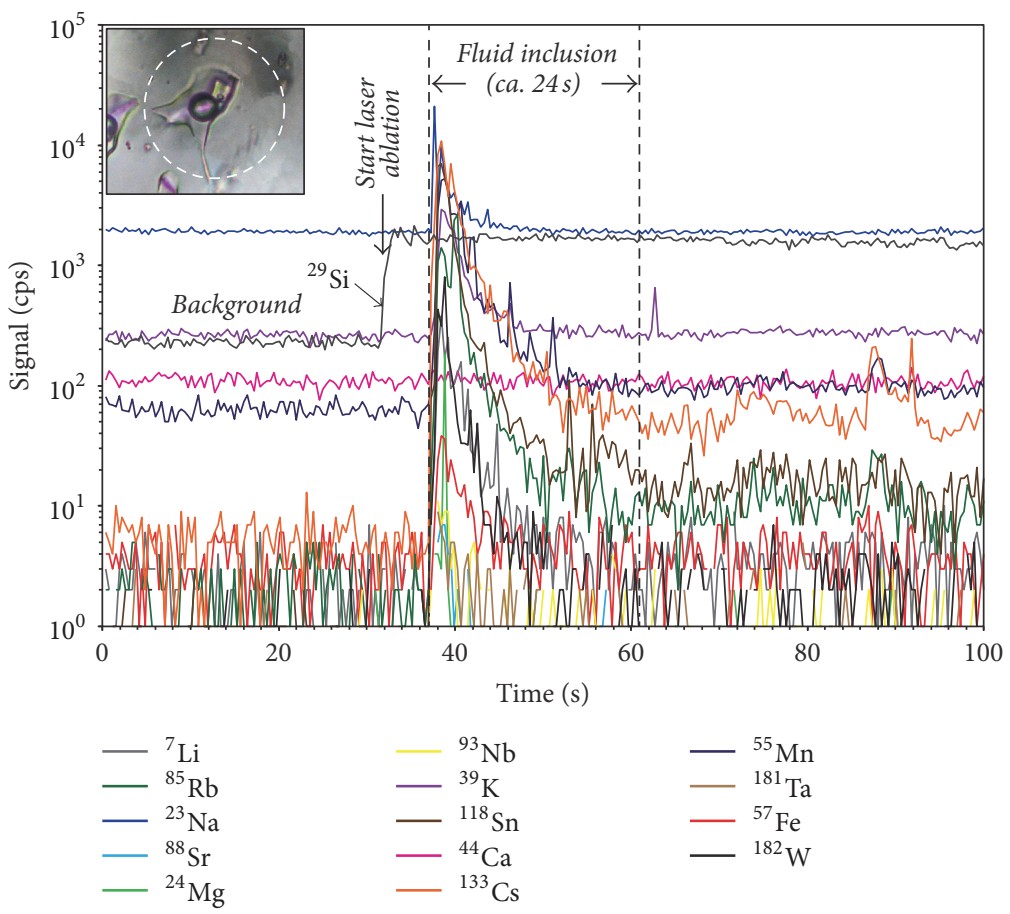

FIGURE 11: Typical LA-ICPMS spectrum of a primary magmatic L1-type fluid inclusion hosted in a globular quartz crystal from the Beauvoir granite (sample B1-379a; FI n A6b). The analysed fluid inclusion (picture in inset) is $17 \mu \mathrm{m}$ in size and was ablated using a laser spot diameter of $32 \mu \mathrm{m}$ (dashed white circle).

\subsubsection{Fluid Inclusions in the La Bosse Stockwork}

L1-Type Fluid Inclusions $(n=3)$. They have very high contents in $\mathrm{Na}(106,250-112,950 \mathrm{ppm}), \mathrm{Fe}(58,600-141,800 \mathrm{ppm})$, Mn (25,300-115,200 ppm), and K (19,350-58,500 ppm), high contents in Cs $(9,750-14,800 \mathrm{ppm})$, and moderate contents in $\mathrm{Rb}(1,130-1,940 \mathrm{ppm})$, Li (5,740-9,050 ppm), Sn (580-5,870 ppm), W (185-230 ppm), and Sr (64-200 ppm). Their $\mathrm{Na} / \mathrm{Li}$ and $\mathrm{Na} / \mathrm{K}$ ratios range from 12 to 20 and 1.9 to 5.5 , respectively.

V2-Type Fluid Inclusions $(n=3)$. They show the lowest concentrations compared with the L1- and L2-type fluid inclusions in the La Bosse stockwork. Their composition is dominated by high contents in $\mathrm{Na}(5,500-27,150 \mathrm{ppm})$, $\mathrm{K}$ (10,150-21,360 ppm), and Fe (16,600-49,200 ppm) and moderate contents in Cs $(370-5,950 \mathrm{ppm}), \mathrm{Sn}(60-$ $26,200 \mathrm{ppm}), \mathrm{Rb}(560-5,230 \mathrm{ppm}), \mathrm{Mn}(450-25,200 \mathrm{ppm})$, $\mathrm{Mg}(1,925-21,250 \mathrm{ppm}), \mathrm{Sr}(54-630 \mathrm{ppm}), \mathrm{W}$ (220-480 ppm), and $\mathrm{Li}(2,740-5,930 \mathrm{ppm})$. Their $\mathrm{Na} / \mathrm{Li}$ and $\mathrm{Na} / \mathrm{K}$ ratios are comprised between 0.9 and 6.5 and 0.5 and 2.6, respectively.

L2-Type Fluid Inclusions $(n=4)$. They have very high contents in $\mathrm{Na}(141,300-144,400 \mathrm{ppm}), \mathrm{K}(51,500-166,500 \mathrm{ppm}), \mathrm{Fe}$ (54,700-232,400 ppm), and Cs (10,900-83,600 ppm), high contents in Sn (2,215-21,600 ppm) and $\mathrm{Mn} \mathrm{(33,350-}$ $98,950 \mathrm{ppm})$, and moderate contents in $\mathrm{Rb}(2,410-$ 7,400 ppm), W (240-1,310 ppm), Li (4,260-10,370 ppm), and $\mathrm{Sr}(91-560 \mathrm{ppm})$. In some of these fluid inclusions, $\mathrm{Nb}$ (63-110 $\mathrm{ppm})$ and $\mathrm{Ta}(17 \mathrm{ppm})$ were detected. The $\mathrm{Na} / \mathrm{Li}$ and
$\mathrm{Na} / \mathrm{K}$ ratios of the L2-type fluid inclusions range from 14 to 33 and from 0.9 to 2.7 , respectively.

L3-Type Fluid Inclusions $(n=4)$. These fluid inclusions were analysed in the quartz and topaz from the metasomatized stockwork. They are characterized by lower contents in $\mathrm{Na}(13,800-22,050 \mathrm{ppm})$ and $\mathrm{K}(3,000-17,700 \mathrm{ppm})$, relatively high contents in Fe $(24,150-170,500 \mathrm{ppm}), \mathrm{Mn}$ $(21,850-59,550 \mathrm{ppm})$, Cs $(1,150-20,800 \mathrm{ppm})$, and Sn (200$14,900 \mathrm{ppm})$, moderate contents in $\mathrm{Rb}(610-3,340 \mathrm{ppm})$, Sr (15-4,520 ppm), Li (925-7,610 ppm), and W (920-1,400 $\mathrm{ppm}$ ), and low contents in $\mathrm{Nb}$ (57-160 ppm) and $\mathrm{Ta}(1.8 \mathrm{ppm})$. The $\mathrm{Na} / \mathrm{Li}$ and $\mathrm{Na} / \mathrm{K}$ ratios are comprised between 2.9 and 19 and 1.2 and 5.9 , respectively.

\section{Discussion}

5.1. Magmatic Signature of the Early Primary Fluids from the Beauvoir Granite. The L1-type fluid inclusions display all the characteristics expected for a primary fluid exsolved from the Beauvoir granite at the magmatic-hydrothermal transition. Microthermometric data show that this is a high-salinity fluid (17-28 wt.\% $\mathrm{NaCl}$ eq), trapped at high temperature (500 to $\left.>600^{\circ} \mathrm{C}\right)$, which is also Li-rich $\left(T_{\mathrm{e}}<-70^{\circ} \mathrm{C}\right)$ with low $\mathrm{Na} / \mathrm{Li}$ $\sim 5$ and low $\mathrm{Na} / \mathrm{K} \leq 5$. These temperatures are close to the solidus temperature of $550-600^{\circ} \mathrm{C}$ at $1 \mathrm{kbar}$ for the $\mathrm{B} 1$ facies of the Beauvoir granite as determined experimentally [57]. The high $\mathrm{Na} / \mathrm{K}(\geq 1)$ ratios are typical of magmatic fluids equilibrated with a granitic melt $[27,28,58]$, whereas the low $\mathrm{Na} / \mathrm{Li}(\leq 5)$ ratios indicate that the fluid was derived from a 

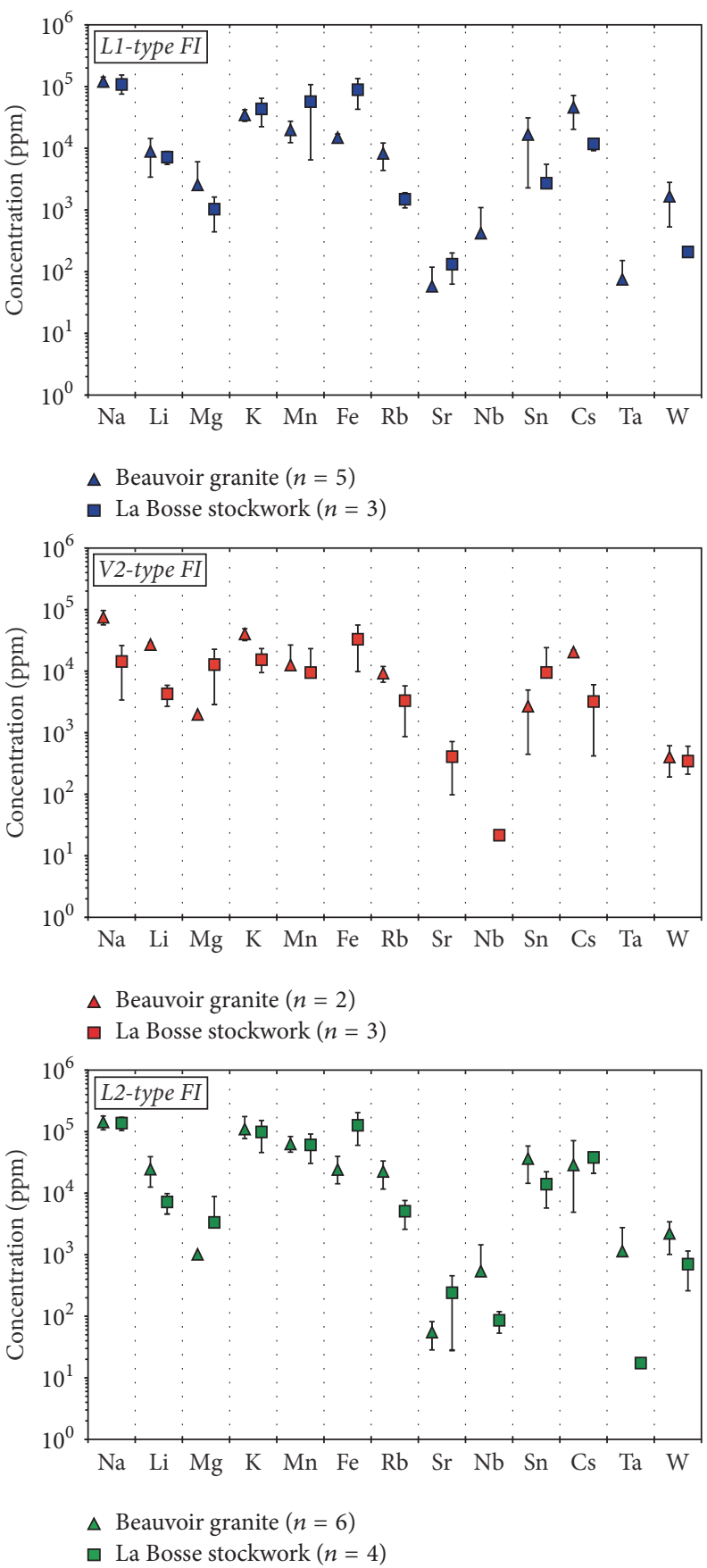

Figure 12: Minor and trace elements contents in L1-, V2- and L2-types fluid inclusions (FI) from the Beauvoir granite and the La Bosse stockwork determined by LA-ICPMS. The values and error bars correspond, respectively, to the averages and standard deviations of the concentrations determined by LA-ICPMS for each fluid inclusion assemblage.

Li-rich magma [59]. Previous preliminary LIBS analysis on L1-type fluid inclusions found in topaz from the Beauvoir granite yielded to lower $\mathrm{Na} / \mathrm{Li} \sim 1-3$ [29], which suggest that the very early magmatic fluid may have been even richer in Li. This appears in accordance with the composition of Limicas in the Beauvoir granite, which represent a late phase on the liquid line of descent of the Beauvoir melt under the low pressure of emplacement estimated [57]. Indeed, these Li-micas display complex internal zoning with compositions ranging from Li-muscovite core to zinnwaldite rim and external lepidolite overgrowth, the latter being interpreted as resulting from the early magmatic-hydrothermal transition [60]. The increase in Li content recorded by the chemical composition of Li-micas appears therefore as a proxy of the progressive exsolution of the early Li-rich magmatic fluid (L1) from the Beauvoir granite.

LA-ICPMS analyses of L1-type fluid inclusions reveal that the chemical composition of this magmatic-hydrothermal 


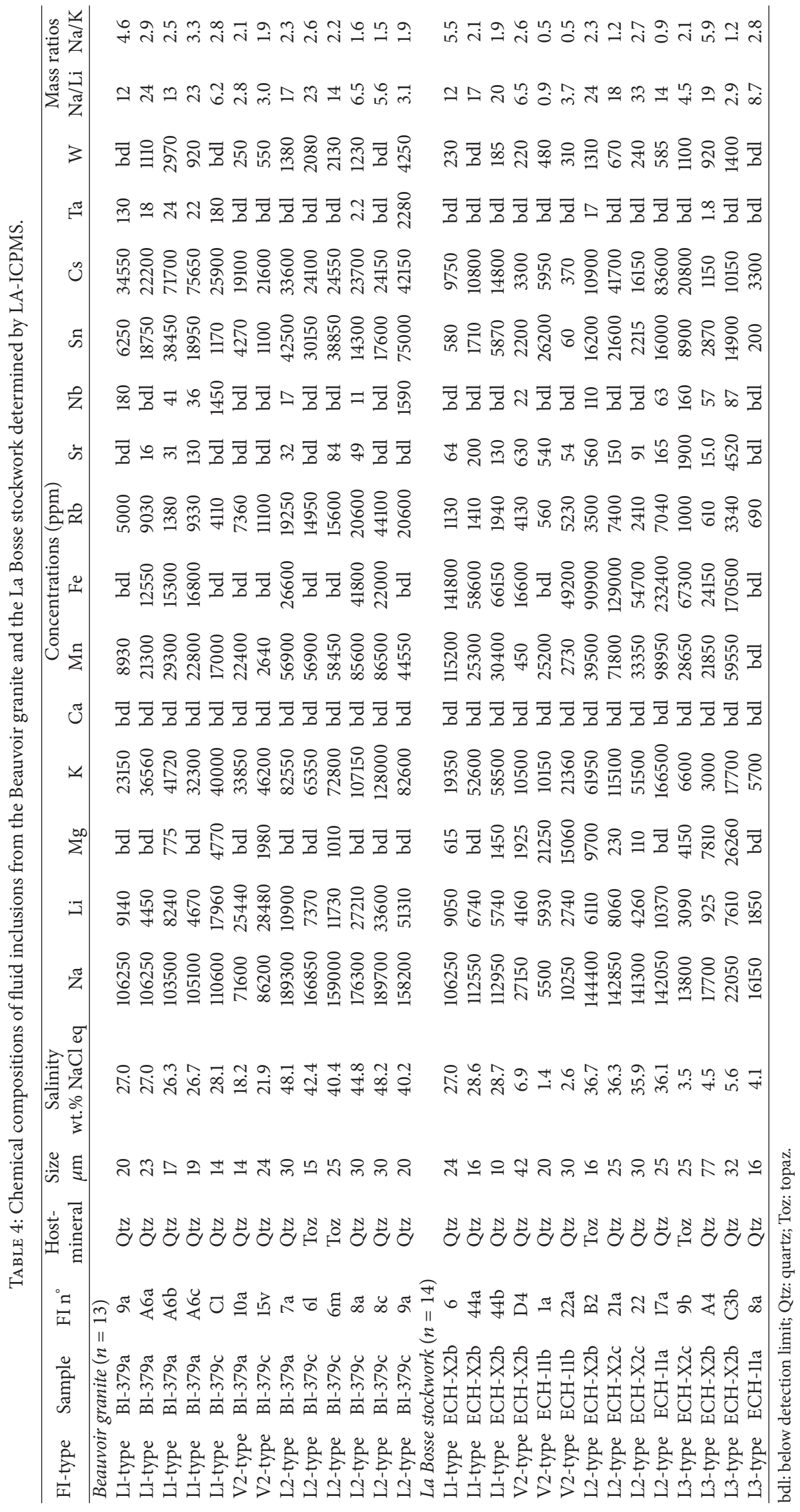


fluid is also rich $\left(10^{2}-10^{4} \mathrm{ppm}\right)$ in $\mathrm{Rb}$ and $\mathrm{Cs}$ and in raremetals ( $\mathrm{W}, \mathrm{Nb}, \mathrm{Ta}$, and $\mathrm{Li}$ ). The very high and highly variable concentration of $\mathrm{Sn}$ in the L1 fluid (up to 4 wt.\% Sn) may be however questioned. Considering that only one microcrystal of cassiterite was found in one L1-type fluid inclusion, as identified by Raman spectrometry, it may be suspected that the high Sn contents in the L1 fluid reflect the heterogeneous trapping of nanoinclusions of cassiterite rather than oversaturation of the magmatic fluid relatively to $\mathrm{SnO}_{2}$. Another possible explanation would be the formation of cassiterite daughter crystals directly from the trapped magmatic fluid, which can reach very high concentrations $(>1 \mathrm{wt} . \%)$ for some metals under supercritical condition [61]. The $\mathrm{Nb}$ content $(36-1,450 \mathrm{ppm})$ is higher on average than the Ta content $(18-180 \mathrm{ppm})$ in the L1 fluid, with an average $\mathrm{Nb} / \mathrm{Ta}$ ratio $\sim$ 5.6. This appears contradictory by comparison with the composition of the B1 facies from the Beauvoir granite, which has higher $\mathrm{Ta}$ than $\mathrm{Nb}$ contents, with $\mathrm{Nb} / \mathrm{Ta}$ ratio in the range of $0.4-0.9$ and $\sim 0.6$ on average $[12,13]$. Similarly $\mathrm{Ta}>\mathrm{Nb}$ contents were also found in other PHP-RMG worldwide, for instance, in Portugal (Argemela granite [62]), France (Montebras granite [13]), Germany (Ehrenfriedersdorf pegmatite [63]), and China (Yichun granite [13]; Laohutou granite [64]). Due to the higher solubility of tantalite relative to that of columbite in peraluminous granitic magmas $[3,65]$, one can expect a late $\mathrm{Ta}$ enrichment relative to $\mathrm{Nb}$ in the residual melt and thus a high $\mathrm{Ta} / \mathrm{Nb}$ ratio in the exsolved magmatic fluid, despite low partition coefficients for $\mathrm{Nb}$ and Ta between an aqueous fluid and silicate melt in granitic systems $\left(D^{\text {fluid-melt }}[\mathrm{Ta}]<D^{\text {fluid-melt }}[\mathrm{Nb}]<0.1\right)[3,66-68]$. Nevertheless, several works on RMG have demonstrated the existence of a late subsolidus fluid-rock interaction between the primary magmatic-hydrothermal fluid and the raremetal minerals (mainly columbite-tantalite) hosted in the granitic melt, leading to a late Ta enrichment as veinlets and overgrowths of tantalite, wodginite, Ta-rich rutile, or Ta-rich cassiterite on early-formed columbite of magmatic origin, following a two-stage evolution and separated in time by a resorption-corrosion event (e.g., [69-72]). These late mineral associations are interpreted as markers of the magmatichydrothermal transition in RMG, thus yielding to relative $\mathrm{Ta}$ depletion and $\mathrm{Nb}$ enrichment in the exsolved magmatichydrothermal fluid. In the B1 facies from the Beauvoir granite, replacement of early magmatic columbite by late microlite was also evidenced and was interpreted as the interaction of the late magmatic fluid with the early Nb-Ta oxides [73]. This may therefore suggest the higher mobility of $\mathrm{Nb}$ compared to Ta in the magmatic-hydrothermal fluid derived from the Beauvoir granite, in accordance with the $\mathrm{Nb}>\mathrm{Ta}$ contents determined in the L1-type fluid inclusions, despite a low $\mathrm{Nb} / \mathrm{Ta}$ ratio initially in the Beauvoir granite.

Comparing the composition of the L1-type fluid inclusions contained in the primary quartz and topaz from the Beauvoir granite with the whole-rock composition of the B1 facies (Figure 13), it appears that the primary L1 fluid is more enriched on average for most of the measured elements (W, $\mathrm{Nb}, \mathrm{Mg}, \mathrm{Fe}, \mathrm{Mn}, \mathrm{Cs}, \mathrm{Sn}, \mathrm{Rb}$, and $\mathrm{Na}$ ). Ta and $\mathrm{K}$ have similar concentrations in the B1 granite and in the L1 fluid, suggesting

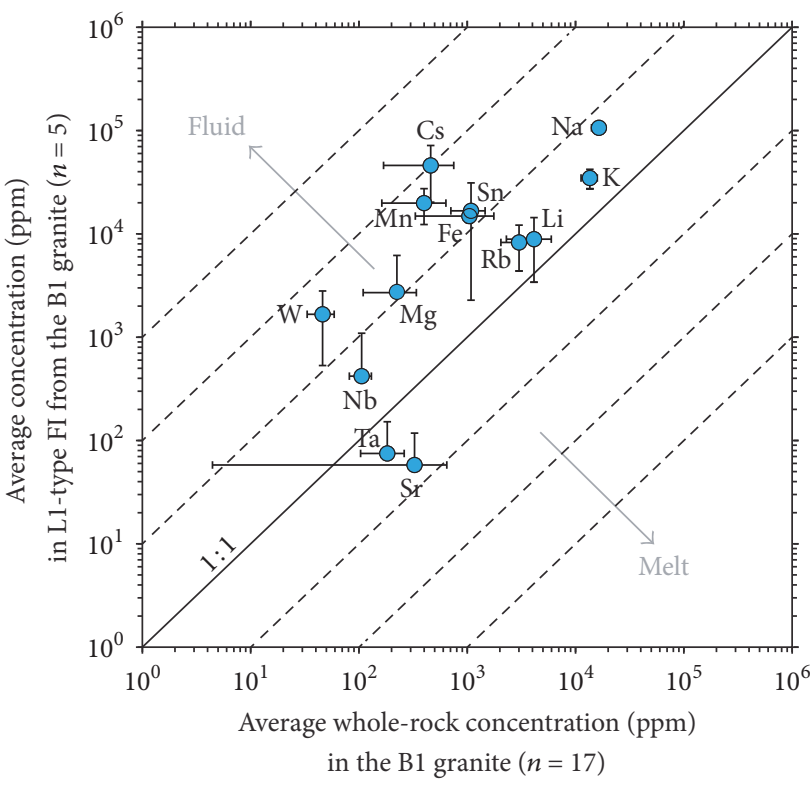

FIGURE 13: Average concentration of L1-type fluid inclusions (FI) contained in primary quartz from the Beauvoir B1 granite determined by LA-ICPMS $(n=5)$ versus average whole-rock concentration of the B1 granite $(n=17)$ compiled from Cuney et al. [12] and Raimbault et al. [13].

no significant fluid/melt partitioning. Ca was systematically below the limits of detection (LOD 3,000 ppm) in the L1-type fluid inclusions, while $\mathrm{Sr}$ is at low concentrations $(10-100 \mathrm{ppm})$. This is in contrast with the relatively high contents in the $\mathrm{B} 1$ facies from the Beauvoir granite in both $\mathrm{Ca}(5,000 \mathrm{ppm}$ on average and up to $11,500 \mathrm{ppm}[12,13])$ and $\mathrm{Sr}(325 \mathrm{ppm}$ on average and up to $1,240 \mathrm{ppm}[12,13])$. This discrepancy likely reflects a $\mathrm{Ca}$ and $\mathrm{Sr}$ input from the surroundings micaschists by external fluids, as evidenced for $\mathrm{Sr}$ by the presence of secondary low-temperature minerals of Sr-rich phosphates in the Beauvoir granite [74]. Thus, these results indicate that most of the elements partition preferentially into the magmatic fluid rather than into the crystallizing melt.

$\mathrm{F}$ and $\mathrm{Cl}$ were not measured by LA-ICPMS since they have high first ionization potentials, yielding to elevated LOD due to low sensitivity. However, there are several evidences that the primary magmatic fluids from the Beauvoir granite were $\mathrm{Cl}$-rich, as indicated by (i) the high salinity (up to $28.1 \mathrm{wt} . \% \mathrm{NaCl}$ eq) calculated for the L1-type fluid inclusions and (ii) the high Sn content in the fluid inclusions, although likely overestimated, which suggests that $\mathrm{Sn}$ was transported as $\mathrm{Sn}-\mathrm{Cl}$ complexes in the fluid $[75,76]$. Concerning $\mathrm{F}$, there are also indications for an elevated content of $\mathrm{F}$ in the magmatic fluid. Firstly, despite the low fluid-melt partition coefficient of $\mathrm{F}$ ( $D^{\text {fluid-melt }}[\mathrm{F}]=0.4$ at $650^{\circ} \mathrm{C}$ and $2 \mathrm{kbar}$ [77]), the very high $\mathrm{F}$ content in the $\mathrm{B} 1$ granite $(2.3 \mathrm{wt} . \%$ on average $[12,13])$ implies a high $\mathrm{F}$ concentration in the exsolved fluid. As pointed by Cuney et al. [12], owing to the large F halo around the B1 granitic cupola, which was evidently provided by the exsolved fluid, the initial F content in the Beauvoir 
B1 melt would have been in the order of $4 \mathrm{wt} . \%$. This has been confirmed by in situ electron microprobe analysis of melt inclusions from the B1 facies, which yielded to average F content of 4.9 wt.\% [78]. A similar F content of $4 \mathrm{wt} . \%$ was also measured, for instance, in primary melt inclusions from the Zinnwald RMG [22]. Thus, considering an initial $\mathrm{F}$ content of $4-5 \mathrm{wt} . \%$ in the initial Beauvoir granitic melt and using a fluid-melt partition coefficient of 0.4 [77], an approximate content of 1.6-2.0 wt.\% $\mathrm{F}$ in the exsolved magmatic fluid may be estimated. Secondly, the crystallization of massive topazite and the partial dissolution of the quartz veins in the La Bosse stockwork imply that the magmatic fluid was F- and Al-rich and undersaturated relatively to $\mathrm{SiO}_{2}$ and has slightly interacted with the enclosing rocks. Finally, the relatively high contents of $\mathrm{Nb}$ and $\mathrm{Ta}$ in the L1 fluid are also consistent with a high concentration of $\mathrm{F}$, which has been shown to increase significantly the solubility of $\mathrm{Nb}$ and $\mathrm{Ta}$ in hydrothermal solutions $[79,80]$. This resulted in the precipitation of $\mathrm{Nb}$ (and $\mathrm{Ta}$ ) as columbite-tantalite and wolframoixiolite in microvugs during the topazification of the quartz-ferberite stockwork [42].

\subsection{Chemical Evolution of the Magmatic Fluids Exsolved} from the Beauvoir Granite. The Beauvoir granite constitutes a remarkable example of a PHP-RMG that crosscuts an early quartz-ferberite stockwork with a vertical development of more than $100 \mathrm{~m}$. The studied quartz-topaz vein from the La Bosse stockwork is located at about $100 \mathrm{~m}$ above and several $100 \mathrm{~m}$ laterally from the roof of the granitic cupola (Figure 2). This implies that when the magmatic-hydrothermal fluids exsolved from the B1 granite reached the stockwork, they had circulated through the surrounding micaschists along a distance of several $100 \mathrm{~m}$ and had therefore likely interacted with them. A comparison between the primary fluids (L1, L2, and V2) found within the granite and those in the stockwork should therefore allow characterizing this interaction. At the first order, the different types of fluids encountered in the stockwork are similar to those from the Beauvoir granite. However, at the second order, microthermometric data show a decreasing trend of $T_{\mathrm{H}}$ and salinity in fluid inclusions from the Beauvoir granite to the La Bosse stockwork (Figure 9). The $T_{\mathrm{H}}$ decrease is of 60 to $120^{\circ} \mathrm{C}$ on average from the granite to the stockwork, which may be interpreted in terms of cooling and thermal equilibration around the granitic intrusion. The salinity decrease is of 3 to $10 \mathrm{wt} \% \mathrm{NaCl}$ eq on average, which suggests that the magmatic-hydrothermal fluids were variably diluted by an external low-salinity fluid. A possibility for such fluid may be meteoric water, considering the relatively shallow depth of emplacement $(\sim 3 \mathrm{~km})$ of the Beauvoir granite estimated from fluid inclusion studies [46]. By contrast, there is no direct evidence for interaction of the primary magmatic fluids with metamorphic fluids. The latter were only identified in early fluid inclusions disseminated within the deformed quartz (Q1) of the La Bosse vein system and were interpreted as related to the formation of the W stockwork [46], which precede the emplacement of the Beauvoir granite from ca. $20 \mathrm{Ma}$ [40].

The chemical composition of the L1 fluid exhibits small, but significant, differences between the Beauvoir granite and the La Bosse stockwork (Figure 12). On the one hand, the elements Mg, Rb, Cs, Nb, Ta, Sn, and W decrease; on the other hand $\mathrm{Mn}, \mathrm{Fe}$, and $\mathrm{Sr}$ increase progressively, from the granite to the stockwork. These variations may be interpreted either as recording fluid-rock interactions of the magmatic fluids with the surrounding micaschists, or as direct interactions with the quartz-ferberite stockwork. Similar chemical trends are observed for the L2 and V2 fluids, excepted for Mg and W that show higher concentrations in fluid inclusions from the La Bosse stockwork compared to the Beauvoir granite. The $\mathrm{W}$ enrichment in some V2 fluid inclusions may come from interaction with the ferberite of the stockwork, whereas the lack of $\mathrm{Nb}$ and $\mathrm{Ta}$ in $\mathrm{L} 2$ fluid inclusions may be the result of their trapping in the wolframoixiolite and columbo-tantalite, which crystallized in microvugs within the partially dissolved ferberite. The variations in concentrations observed for the other elements, however, may be due to a direct fluid-rock interaction with the micaschists marked by a gain of $\mathrm{Mn}, \mathrm{Fe}$, and $\mathrm{Sr}$ into the fluid, and by a loss of $\mathrm{Mg}, \mathrm{Rb}, \mathrm{Cs}, \mathrm{Nb}, \mathrm{Ta}, \mathrm{Li}$, and $\mathrm{Sn}$ into the host-rocks. In this regard, the introduction of Sr leached from the micaschists by external fluids into the Beauvoir granite was demonstrated by Charoy et al. [74].

Finally, it remains remarkable that the geochemical signature of the RMG is still preserved in the primary L1-type fluid inclusions from the metasomatized La Bosse stockwork, despite the distance from the granitic cupola $(>100 \mathrm{~m})$ and interaction with the host-rocks and external fluids. Furthermore, the undersaturation relatively to $\mathrm{SiO}_{2}$ of the fluid suggests an overall rapid transfer from the granitic cupola through the surrounding rocks, likely using the quartzferberite vein system as preferential flow channel. Consequently, it may be tentatively proposed that the geochemical signature of fluid inclusions represents a proximal pathfinder for the discovery of hidden rare-metal granitic cupolas in the surroundings of the Echassières granitic complex and more widely in the Limousin area, as well as elsewhere in the world.

\subsection{Element Partitioning between Coexisting Vapour and} Brine during Early Boiling. Determining the major and trace elements composition of coexisting V2- and L2-type fluid inclusions that formed during the early boiling of the primary L1 fluid at ca. $400-520^{\circ} \mathrm{C}$ allows studying the element partitioning between the low-density vapour (V2) and the highdensity brine (L2). Vapour-brine distribution coefficients determined by LA-ICPMS analysis for the coexisting V2- and L2-type fluid inclusions in the Beauvoir granite and in the La Bosse stockwork are shown in Figure 14. In the Beauvoir granite, the majority of the elements ( $\mathrm{Na}, \mathrm{K}, \mathrm{Mn}, \mathrm{Rb}, \mathrm{Sn}, \mathrm{Cs}$, and $\mathrm{W}$ ) partitions preferentially into the brine, whereas only $\mathrm{Mg}$ and $\mathrm{Li}$ are preferentially enriched into the vapour. In the La Bosse stockwork, the trend is almost similar with the only difference that $\mathrm{Li}$ and $\mathrm{Sr}$ are more enriched into the brine. These results are in good agreement with those of Audétat et al. [28] for the Mole granite, thus confirming that most of the elements display a preferential partitioning for the $\mathrm{Cl}$-rich aqueous phase. 


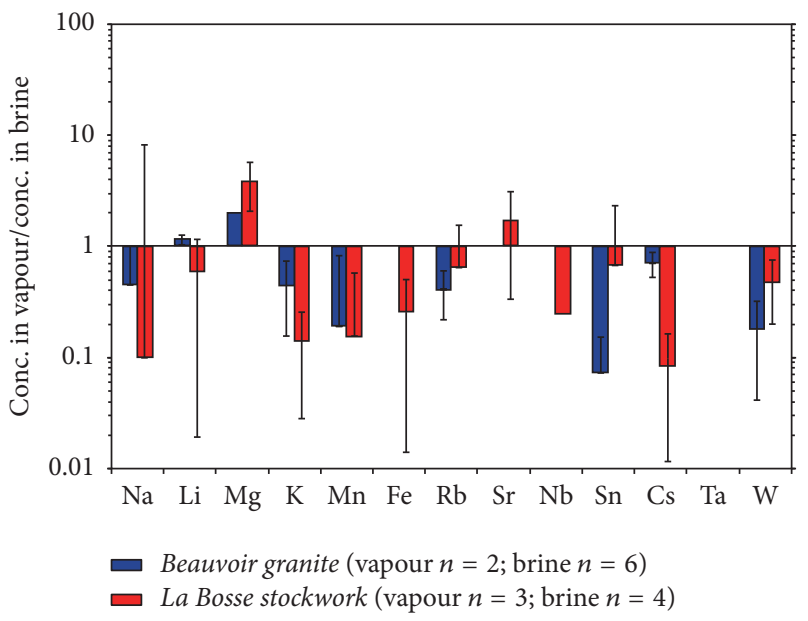

FIGURE 14: Vapour-brine distribution coefficients determined by LA-ICPMS analysis of coexisting V2- and L2-type fluid inclusions from the Beauvoir granite and the La Bosse stockwork. Columns represent the average value calculated for each fluid inclusion population, whereas error bars indicate the standard deviation $(1 \sigma)$ associated with these averages.

\section{Conclusions}

This work allowed characterizing the geochemical signature of the magmatic-hydrothermal fluids exsolved from the Beauvoir rare-metal granite. The different generations of fluid inclusions (L1, L2, V2, and L3) initially identified by Aïssa et al. [46] were retrieved during this study. The L1-type fluid inclusions represent the earliest records of the primary magmatic fluid in the Beauvoir granite. Microthermometric data showed that this fluid is of high temperature (500 to $>600^{\circ} \mathrm{C}$ ) and high salinity (17-28 wt.\% $\mathrm{NaCl}$ eq) and is Lirich $\left(T_{\mathrm{e}}<-70^{\circ} \mathrm{C}\right)$ with $\mathrm{Na} / \mathrm{Li}$ ratios $\sim 5$. LA-ICPMS analyses show that the chemical composition of the L1 fluid is dominated by $\mathrm{Na}, \mathrm{K}, \mathrm{Cs}$, and $\mathrm{Rb}$, with significant concentrations $\left(10^{1}-10^{4} \mathrm{ppm}\right)$ in rare-metals $(\mathrm{W}, \mathrm{Nb}, \mathrm{Ta}, \mathrm{Sn}$, and Li). Boiling of the L1 fluid at ca. $450^{\circ} \mathrm{C}$ yielded by phase separation to a low- to moderate-salinity vapour (V2; $4.7-22 \mathrm{wt} . \% \mathrm{NaCl}$ eq) and a high-salinity brine (L2; 32-48 wt.\% $\mathrm{NaCl}$ eq). LA-ICPMS analyses of these two types of fluid inclusions revealed that the L2-type fluid inclusions have the highest concentrations in metals and show a preferential enrichment in most of the elements ( $\mathrm{Na}, \mathrm{K}, \mathrm{Mn}, \mathrm{Fe}, \mathrm{Rb}, \mathrm{Nb}, \mathrm{Sn}, \mathrm{Cs}$, and W) compared to the V2-type fluid inclusions. The evolution of the exsolved magmatic fluids with distance from the Beauvoir granitic cupola is characterized by a systematic decrease in temperature and salinity. The temperature decrease can be interpreted in terms of cooling and thermal equilibration around the intrusion, whereas the salinity decrease indicates that the exsolved magmatic-hydrothermal fluids were more or less diluted by a low-salinity fluid, possibly of meteoric origin. These results demonstrate that primary fluid inclusions preserved the pristine signature of the magmatichydrothermal fluids in the Beauvoir granite, but also in the metasomatized W stockwork, despite the distance from the granitic cupola $(>100 \mathrm{~m})$ and interaction with external fluids.
Consequently, it is proposed that the geochemical signature of fluid inclusions may serve as a possible pathfinder for the discovery of hidden rare-metal granitic cupolas at Echassières and more widely in the Limousin area, as elsewhere in the world.

\section{Disclosure}

The present address for Matthieu Harlaux is Department of Earth Sciences, University of Geneva, 1205 Geneva, Switzerland, and the present address for Wilédio Marc-Emile Bonzi is Université de Ouagadougou, UFR-SVT, Département de Géologie, 09 BP 848, Ouagadougou 09, Burkina Faso.

\section{Conflicts of Interest}

The authors declare that they have no conflicts of interest.

\section{Acknowledgments}

This work was supported by the French National Research Agency through the national program "Investissements d'Avenir" of the Labex Ressources 21 with Reference ANR10-LABX-21-RESSOURCES21 and has also taken part of the project ERAMIN "New Ores." The authors are grateful to the company Imerys Ceramics France, especially Hubert Sauvage, for their support and access to the Beauvoir mine. The authors thank also Dr Chantal Peiffert and Dr MarieChristine Boiron for technical support in providing analytical data with LA-ICPMS analyses and Dr Marie-Camille Caumon for her help with the Raman spectrometry. The authors are grateful to Dr Rainer Thomas and Dr Li Zhou for their constructive reviews and suggestions. This paper benefited greatly from the careful handling by the Editor Dr Xing Ding.

\section{References}

[1] P. J. Pollard, "A special issue devoted to the geology of rare metal deposits; geology of rare metal deposits; an introduction and overview," Economic Geology, vol. 90, no. 3, pp. 489-494, 1995.

[2] R. L. Linnen, M. Van Lichtervelde, and P. Černý, "Granitic pegmatites as sources of strategic metals," Elements, vol. 8, no. 4, pp. 275-280, 2012.

[3] R. L. Linnen and M. Cuney, "Granite-related rare-element deposits and experimental constraints on Ta-Nb-W-Sn-Zr-Hf mineralization," in Rare-Element Geochemistry and Mineral Deposits Short Course Notes, R. L. Linnen and I. M. Samson, Eds., vol. 17, pp. 45-68, Geological Association of Canada, Canada, 2005.

[4] P. Černý and T. S. Ercit, “The classification of granitic pegmatites revisited," The Canadian Mineralogist, vol. 43, no. 6, pp. 20052026, 2005.

[5] P. Černý, P. L. Blevin, M. Cuney, and D. London, "GraniteRelated Ore Deposits," Economic Geology 100 th anniversary volume, vol. 107, no. 2, pp. 383-384, 2005.

[6] Y. Chen, A. H. Clark, E. Farrar, H. A. H. P. Wasteneys, M. J. Hodgson, and A. V. Bromley, "Diachronous and independent histories of plutonism and mineralization in the Cornubian Batholith, southwest England," Journal of the Geological Society, vol. 150, no. 6, pp. 1183-1191, 1993. 
[7] C. Marignac and M. Cuney, "Ore deposits of the French Massif Central: Insight into the metallogenesis of the Variscan collision belt," Mineralium Deposita, vol. 34, no. 5-6, pp. 472-504, 1999.

[8] M. Cuney, P. Alexandrov, C. L. C. De Veslud et al., "The timing of W-Sn-rare metals mineral deposit formation in the Western Variscan chain in their orogenic setting: The case of the Limousin area (Massif Central, France)," Geological Society of London, Special Publication, vol. 204, pp. 213-228, 2002.

[9] J. Melleton, E. Gloaguen, D. Frei, M. Novák, and K. Breiter, "How are the emplacement of rare-element pegmatites, regional metamorphism and magmatism interrelated in the Moldanubian domain of the Variscan Bohemian Massif, Czech Republic?" The Canadian Mineralogist, vol. 50, no. 6, pp. 1751-1773, 2012.

[10] J. Melleton, E. Gloaguen, and D. Frei, "Rare-elements (Li-Be-Ta$\mathrm{Sn}-\mathrm{Nb}$ ) magmatism in the European Variscan Belt, a review," in Proceedings of the 13th Biennial SGA Meeting, A. S. AndréMayer, M. Cathelineau, P. Muchez, E. Pirard, and S. Sindern, Eds., vol. 2, pp. 24-27, France, 2015.

[11] M. Cuney and A. Autran, "Objectifs généraux du projet GPF Echassières $n^{\circ} 1$ et résultats essentiels acquis par le forage de 900 $\mathrm{m}$ sur le granite albitique à topaze-lépidolite de Beauvoir," in Géologie profonde de la France, Echassières : le forage scientifique. Une clé pour la compréhension des mécanismes magmatiques et hydrothermaux associés aux granites à métaux rares, $\mathrm{M}$. Cuney and A. Autran, Eds., pp. 7-24, Géologie de la France, 1987.

[12] M. Cuney, C. Marignac, and A. Weisbrod, "The Beauvoir topazlepidolite albite granite (Massif Central, France) : the disseminated magmatic Sn-Li-Ta-Nb-Be mineralization," Economic Geology, vol. 87, no. 7, pp. 1766-1794, 1992.

[13] L. Raimbault, M. Cuney, C. Azencott, J. L. Duthou, and J. L. Joron, "Geochemical evidence for a multistage magmatic genesis of Ta-Sn-Li mineralization in the granite at Beauvoir, French Massif Central," Economic Geology, vol. 90, no. 3, pp. 548-576, 1995.

[14] K. Breiter, A. Müller, J. Leichmann, and A. Gabašová, “Textural and chemical evolution of a fractionated granitic system: The Podlesí stock, Czech Republic," Lithos, vol. 80, no. 1-4, pp. 323345, 2005.

[15] Z. Johan and V. Johan, "Accessory minerals of the Cínovec (Zinnwald) granite cupola, Czech Republic: Indicators of petrogenetic evolution," Mineralogy and Petrology, vol. 83, no. 1-2, pp. 113-150, 2005.

[16] J. D. Webster, J. R. Holloway, and R. L. Hervig, "Partitioning of lithophile trace elements between $\mathrm{H}_{2} \mathrm{O}$ and $\mathrm{H}_{2} \mathrm{O}+\mathrm{CO}_{2}$ fluids and topaz rhyolite melt," Economic Geology, vol. 84, no. 1, pp. 116-134, 1989.

[17] R. L. Linnen, "The solubility of Nb-Ta-Zr-Hf-W in granitic melts with $\mathrm{Li}$ and $\mathrm{Li}+\mathrm{F}$ : Constraints for mineralization in rare metal granites and pegmatites," Economic Geology, vol. 93, no. 7, pp. 1013-1025, 1998.

[18] I. V. Veksler, "Liquid immiscibility and its role at the magmatichydrothermal transition: a summary of experimental studies," Chemical Geology, vol. 210, no. 1-4, pp. 7-31, 2004.

[19] I. V. Veksler, "Element enrichment and fractionation by magmatic aqueous fluids: experimental constraints on melt-fluid immiscibility and element partitioning," in Rare-Element Geochemistry and Mineral Deposits Short Course Notes, R. L. Linnen and I. M. Samson, Eds., vol. 17, pp. 69-85, Geological Association of Canada, Canada, 2005.

[20] R. Thomas, H.-J. Förster, and W. Heinrich, "The behaviour of boron in a peraluminous granite-pegmatite system and associated hydrothermal solutions: a melt and fluid-inclusion study," Contributions to Mineralogy and Petrology, vol. 144, no. 4, pp. 457-472, 2003.

[21] R. Thomas, H.-J. Förster, K. Rickers, and J. D. Webster, "Formation of extremely F-rich hydrous melt fractions and hydrothermal fluids during differentiation of highly evolved tin-granite magmas: a melt/fluid-inclusion study," Contributions to Mineralogy and Petrology, vol. 148, no. 5, pp. 582-601, 2005.

[22] J. Webster, R. Thomas, H.-J. Förster, R. Seltmann, and C. Tappen, "Geochemical evolution of halogen-enriched granite magmas and mineralizing fluids of the Zinnwald tin-tungsten mining district, Erzgebirge, Germany," Mineralium Deposita, vol. 39, no. 4, pp. 452-472, 2004.

[23] E. V. Badanina, I. V. Veksler, R. Thomas, L. F. Syritso, and R. B. Trumbull, "Magmatic evolution of Li-F, rare-metal granites: a case study of melt inclusions in the Khangilay complex, Eastern Transbaikalia (Russia)," Chemical Geology, vol. 210, no. 1-4, pp. 113-133, 2004.

[24] K. Rickers, R. Thomas, and W. Heinrich, "Trace-element analysis of individual synthetic and natural fluid inclusions with synchrotron radiation XRF using Monte Carlo simulations for quantification," European Journal of Mineralogy, vol. 16, no. 1, pp. 23-35, 2004.

[25] K. Rickers, R. Thomas, and W. Heinrich, “The behavior of trace elements during the chemical evolution of the $\mathrm{H}_{2} \mathrm{O}-$, B-, and F-rich granite-pegmatite-hydrothermal system at Ehrenfriedersdorf, Germany: a SXRF study of melt and fluid inclusions," Mineralium Deposita, vol. 41, no. 3, pp. 229-245, 2006.

[26] A. Y. Borisova, R. Thomas, S. Salvi, F. Candaudap, A. Lanzanova, and J. Chmeleff, "Tin and associated metal and metalloid geochemistry by femtosecond LA-ICP-QMS microanalysis of pegmatite-leucogranite melt and fluid inclusions: New evidence for melt-melt-fluid immiscibility," Mineralogical Magazine, vol. 76, no. 1, pp. 91-113, 2012.

[27] A. Audétat, D. Günther, and C. A. Heinrich, "Magmatichydrothermal evolution in a fractionating granite: A microchemical study of the Sn-W-F-mineralized mole granite (Australia)," Geochimica et Cosmochimica Acta, vol. 64, no. 19, pp. 3373-3393, 2000.

[28] A. Audétat, D. Güther, and C. A. Heinrich, "Causes for LargeScale Metal Zonation around Mineralized Plutons: Fluid Inclusion LA-ICP-MS Evidence from the Mole Granite, Australia," Economic Geology, vol. 95, no. 8, pp. 1563-1581, 2000.

[29] C. Fabre, MC. Boiron, C. Marignac, and M. Aïssa, "Li-F-rich magmatic fluids exsolved from rare metal granites: the example of the Beauvoir granite (French Massif Central); a microthermometric and LIBS study. XVI ECROFI abstract," Porto, vol. 7, pp. 145-147, 2001.

[30] M. Faure, J.-M. Lardeaux, and P. Ledru, "A review of the pre-Permian geology of the Variscan French Massif Central," Comptes Rendus - Geoscience, vol. 341, no. 2-3, pp. 202-213, 2009.

[31] J. L. Duthou, J. M. Cantagrel, J. Didier, and Y. Vialette, "Palaeozoic granitoids from the French Massif Central: age and origin studied by ${ }^{87} \mathrm{Rb}-{ }^{87} \mathrm{Sr}$ system," Physics of the Earth and Planetary Interiors, vol. 35, no. 1-3, pp. 131-144, 1984.

[32] C. Cartannaz, P. Rolin, A. Cocherie et al., "Characterization of wrench tectonics from dating of syn- to post-magmatism in the north-western French Massif Central," International Journal of Earth Sciences, vol. 96, no. 2, pp. 271-287, 2007. 
[33] C. Pin, "Sr-Nd isotopic study of igneous and metasedimentary enclaves in some Hercynian granitoids from the Massif Central," in Enclaves and granite petrology, J. Didier and B. Barbarin, Eds., vol. 13, pp. 333-343, Elsevier, France, 1991.

[34] M. Faure, J. Grolier, and J. Pons, "Extensional ductile tectonics of the Sioule metamorphic series (Variscan French Massif Central)," Geologische Rundschau, vol. 82, no. 3, pp. 461-474, 1993.

[35] B. Schulz, "EMP-monazite age controls on P-T paths of garnet metapelites in the Variscan inverted metamorphic sequence of la Sioule, French Massif Central," Bulletin de la Société Géographique de France, vol. 180, no. 3, pp. 271-282, 2009.

[36] D. Do Couto, M. Faure, R. Augier et al., "Monazite U-Th-Pb EPMA and zircon $\mathrm{U}-\mathrm{Pb}$ SIMS chronological constraints on the tectonic, metamorphic, and thermal events in the inner part of the Variscan orogen, example from the Sioule series, French Massif Central," International Journal of Earth Sciences, vol. 105, no. 2, pp. 557-579, 2016.

[37] J. L. Vigneresse, "Organisation tridimensionnelle du massif d'Echassières et bilan des mesures géophysiques de surface," in In Géologie profonde de la France, Echassières : le forage scientifique. Une clé pour la compréhension des mécanismes magmatiques et hydrothermaux associés aux granites à métaux rares, M. Cuney and A. Autran, Eds., pp. 27-32, Géologie de la France, France, 1987.

[38] A. Cheilletz, D. Archibald, M. Cuney, and B. Charoy, "Ages ${ }^{40} \mathrm{Ar} /{ }^{39} \mathrm{Ar}$ du leucogranite à topaze-lépidolite de Beauvoir et des pegmatites sodolithiques de Chédeville (Nord Massif Central, France)," Significations pétrologique et géodynamique. Comptes Rendus de l'Académie des Sciences, vol. 315, pp. 329-336, 1992.

[39] T. Merceron, P. Vieillard, A.-M. Fouillac, and A. Meunier, "Hydrothermal alterations in the Echassières granitic cupola (Massif central, france)," Contributions to Mineralogy and Petrology, vol. 112, no. 2-3, pp. 279-292, 1992.

[40] M. Harlaux, R. L. Romer, J. Mercadier, C. Morlot, C. Marignac, and M. Cuney, "40 Ma of hydrothermal W mineralization during the Variscan orogenic evolution of the French Massif Central revealed by $\mathrm{U}-\mathrm{Pb}$ dating of wolframite," Mineralium Deposita, pp. 1-31, 2017.

[41] G. Aubert, "Les coupoles granitiques de Montebras et d'Echassières (Massif Central Français) et la genèse de leurs minéralisations en étain, lithium, tungstène et béryllium," Mémoires du BRGM, vol. 46, p. 350, 1969.

[42] M. Aïssa, C. Marignac, and A. Weisbrod, "Le stockwerk à ferbérite d'Echassières : évolution spatiale et temporelle ; cristallochimie des ferbérites," in Géologie profonde de la France, d'Echassières : le forage scientifique. Une clé pour la compréhension des mécanismes magmatiques et hydrothermaux associés aux granites à métaux rares, M. Cuney and A. Autran, Eds., pp. 311-333, Géologie de la France, France, 1987.

[43] R. J. Bodnar, "Introduction to aqueous-electrolyte fluid inclusions. Mineralogical Association of Canada," Short Course, vol. 32, pp. 81-99, 2003.

[44] D. Michel, M. Christophe, C. Teddy et al., "Investigation of the $\mathrm{H}_{2} \mathrm{O}-\mathrm{NaCl}-\mathrm{LiCl}$ system: A synthetic fluid inclusion study and thermodynamic modeling from $-50 \circ$ to $+100 \circ \mathrm{C}$ and up to 12 mol/kg," Economic Geology, vol. 105, no. 2, pp. 329-338, 2010.

[45] M.-C. Caumon, J. Dubessy, P. Robert, and A. Tarantola, "Fused-silica capillary capsules (FSCCs) as reference synthetic aqueous fluid inclusions to determine chlorinity by Raman spectroscopy," European Journal of Mineralogy, vol. 25, no. 5, pp. 755-763, 2013.
[46] M. Aïssa, A. Weisbrod, and C. Marignac, "Caractéristiques chimiques et thermodynamiques des circulations hydrothermales du site d'Echassières," in Géologie profonde de la France, Echassières : le forage scientifique. Une clé pour la compréhension des mécanismes magmatiques et hydrothermaux associés aux granites à métaux rares, M. Cuney and A. Autran, Eds., pp. 335350, Géologie de la France, 1987.

[47] E. Roedder, “The origin of inclusions.," Reviews in Mineralogy, Volume 12: Fluid Inclusions, (Mineralogical Society of America), pp. 11-45, 1984.

[48] E. Roedder, "Fluid inclusion analysis-Prologue and epilogue," Geochimica et Cosmochimica Acta, vol. 54, no. 3, pp. 495-507, 1990.

[49] L. W. Diamond, "Review of the systematics of $\mathrm{CO}_{2}-\mathrm{H}_{2} \mathrm{O}$ fluid inclusions," Lithos, vol. 55, no. 1-4, pp. 69-99, 2001.

[50] D. Günther, A. Audétat, R. Frischknecht, and C. A. Heinrich, "Quantitative analysis of major, minor and trace elements in fluid inclusions using laser ablation-inductively coupled plasma mass spectrometry," Journal of Analytical Atomic Spectrometry, vol. 13, no. 4, pp. 263-270, 1998.

[51] K. P. Jochum, U. Weis, B. Stoll et al., "Determination of reference values for NIST SRM 610-617 glasses following ISO guidelines," Geostandards and Geoanalytical Research, vol. 35, no. 4, pp. 397429, 2011.

[52] M. B. Fricker, Design of ablation cells for LA-ICP-MS : from modeling to high spatial resolution analysis applications. [Ph. D. Thesis], 2012.

[53] M. M. Allan, B. W. D. Yardley, L. J. Forbes, K. I. Shmulovich, D. A. Banks, and T. J. Shepherd, "Validation of LA-ICP-MS fluid inclusion analysis with synthetic fluid inclusions," American Mineralogist, vol. 90, no. 11-12, pp. 1767-1775, 2005.

[54] H. P. Longerich, S. E. Jackson, and D. Günther, "Laser ablation inductively coupled plasma mass spectrometric transient signal data acquisition and analyte concentration calculation," Journal of Analytical Atomic Spectrometry, vol. 11, no. 9, pp. 899-904, 1996.

[55] C. Monnin, M. Dubois, N. Papaiconomou, and J.-P. Simonin, "Thermodynamics of the $\mathrm{LiCl}+\mathrm{H}_{2} \mathrm{O}$ system," Journal of Chemical \& Engineering Data, vol. 47, no. 6, pp. 1331-1336, 2002.

[56] J. Dubessy, T. Lhomme, M.-C. Boiron, and F. Rull, "Determination of chlorinity in aqueous fluids using Raman spectroscopy of the stretching band of water at room temperature: Application to fluid inclusions," Applied Spectroscopy, vol. 56, no. 1, pp. 99-106, 2002.

[57] M. Pichavant, M. Boher, J. F. Stenger, M. Aïssa, and B. Charoy, "Relations de phase des granites de Beauvoir à 1 et 3 kbar, en condition de saturation en $\mathrm{H}_{2} \mathrm{O}$," in Géologie profonde de la France, Echassières : le forage scientifique. Une clé pour la compréhension des mécanismes magmatiques et hydrothermaux associés aux granites à métaux rares, $\mathrm{M}$. Cuney and A. Autran, Eds., pp. 77-85, Géologie de la France, France, 1987.

[58] A. H. Rankin, M. H. Ramsey, B. Coles, F. Van Langevelde, and C. R. Thomas, "The composition of hypersaline, iron-rich granitic fluids based on laser-ICP and Synchrotron-XRF microprobe analysis of individual fluid inclusions in topaz, Mole granite, eastern Australia," Geochimica et Cosmochimica Acta, vol. 56, no. 1, pp. 67-79, 1992.

[59] M. Cathelineau, C. Marignac, M.-C. Boiron, G. Gianelli, and M. Puxeddu, "Evidence for Li-rich brines and early magmatic fluid-rock interactionin the Larderello geothermal system," Geochimica et Cosmochimica Acta, vol. 58, no. 3, pp. 1083-1099, 1994. 
[60] G. Monier, B. Charoy, M. Cuney, D. Ohnenstetter, and J. L. Robert, "Evolution spatiale et temporelle de la composition des micas du granite albitique à topaze-lépidolite de Beauvoir," in In Géologie profonde de la France, Echassières : le forage scientifique. Une clé pour la compréhension des mécanismes magmatiques et hydrothermaux associés aux granites à métaux rares, M. Cuney and A. Autran, Eds., pp. 179-188, Géologie de la France, France, 1987.

[61] R. Thomas and P. Davidson, "Revisiting complete miscibility between silicate melts and hydrous fluids, and the extreme enrichment of some elements in the supercritical state - Consequences for the formation of pegmatites and ore deposits," Ore Geology Reviews, vol. 72, pp. 1088-1101, 2016.

[62] B. Charoy and F. Noronha, "Multistage growth of a rareelement, volatile-rich microgranite at argemela (Portugal)," Journal of Petrology, vol. 37, no. 1, pp. 73-94, 1996.

[63] J. D. Webster, R. Thomas, D. Rhede, H.-J. Förster, and R. Seltmann, "Melt inclusions in quartz from an evolved peraluminous pegmatite: Geochemical evidence for strong tin enrichment in fluorine-rich and phosphorus-rich residual liquids," Geochimica et Cosmochimica Acta, vol. 61, no. 13, pp. 2589-2604, 1997.

[64] J.-C. Zhu, R.-K. Li, F.-C. Li, X.-L. Xiong, F.-Y. Zhou, and X.L. Huang, "Topaz-albite granites and rare-metal mineralization in the Limu district, Guangxi Province, Southeast China," Mineralium Deposita, vol. 36, no. 5, pp. 393-405, 2001.

[65] R. L. Linnen and H. Keppler, "Columbite solubility in granitic melts: Consequences for the enrichment and fractionation of $\mathrm{Nb}$ and Ta in the Earth's crust," Contributions to Mineralogy and Petrology, vol. 128, no. 2-3, pp. 213-227, 1997.

[66] H. Keppler, "Constraints from partitioning experiments on the composition of subduction-zone fluids," Nature, vol. 380, no. 6571, pp. 237-240, 1996.

[67] V. Y. Chevychelov, G. P. Zaraisky, S. E. Borisovskii, and D. A. Borkov, "Effect of melt composition and temperature on the partitioning of $\mathrm{Ta}, \mathrm{Nb}, \mathrm{Mn}$, and $\mathrm{F}$ between granitic (alkaline) melt and fluorine-bearing aqueous fluid: Fractionation of Ta and $\mathrm{Nb}$ and conditions of ore formation in rare-metal granites," Petrology, vol. 13, no. 4, pp. 305-321, 2005.

[68] G. P. Borodulin, V. Y. Chevychelov, and G. P. Zaraysky, "Experimental study of partitioning of tantalum, niobium, manganese, and fluorine between aqueous fluoride fluid and granitic and alkaline melts," Doklady Earth Sciences, vol. 427, no. 1, pp. 868873, 2009.

[69] K. Breiter, R. Škoda, and P. Uher, "Nb-Ta-Ti-W-Sn-oxide minerals as indicators of a peraluminous P- and F-rich granitic system evolution: Podlesí, Czech Republic," Mineralogy and Petrology, vol. 91, no. 3-4, pp. 225-248, 2007.

[70] L. Bouabsa, C. Marignac, R. Chabbi, and M. Cuney, "The Filfila (NE Algeria) topaz-bearing granites and their rare metal minerals: Petrologic and metallogenic implications," Journal of African Earth Sciences, vol. 56, no. 2-3, pp. 107-113, 2010.

[71] Z.-Y. Zhu, R.-C. Wang, X.-D. Che, J.-C. Zhu, X.-L. Wei, and X. Huang, "Magmatic-hydrothermal rare-element mineralization in the Songshugang granite (northeastern Jiangxi, China): Insights from an electron-microprobe study of $\mathrm{Nb}-\mathrm{Ta}-\mathrm{Zr}$ minerals," Ore Geology Reviews, vol. 65, no. 4, pp. 749-760, 2015.

[72] C. Marignac, D. E. Aïssa, L. Bouabsa, M. Kesraoui, and S. Nedjari, "The Hoggar Gold and Rare Metals Metallogenic Province of the Pan-African Tuareg Shield (Central Sahara, South Algeria): An Early Cambrian Echo of the Late Ediacaran Murzukian Event?" in Mineral Deposits of North Africa, Mineral
Resource Reviews, pp. 371-404, Springer International Publishing, Cham, Switzerland, 2016.

[73] D. Ohnenstetter and P. Piantone, "Pyrochlore-group minerals in the Beauvoir peraluminous leucogranite, Massif Central, France," The Canadian Mineralogist, vol. 30, no. 3, pp. 771-784, 1992.

[74] B. Charoy, M. Chaussidon, C. Le Carlier de Veslud, and J. L. Duthou, "Evidence of Sr mobility in and around the albitelepidolite-topaz granite of Beauvoir (France): An in-situ ion and electron probe study of secondary Sr-rich phosphates," Contributions to Mineralogy and Petrology, vol. 145, no. 6, pp. 673-690, 2003.

[75] K. J. Jackson and H. C. Helgeson, "Chemical and thermodynamic constraints on the hydrothermal transport and deposition of tin: I. Calculation of the solubility of cassiterite at high pressures and temperatures," Geochimica et Cosmochimica Acta, vol. 49, no. 1, pp. 1-22, 1985.

[76] C. A. Heinrich, "The chemistry of hydrothermal tin(-tungsten) ore deposition," Economic Geology, vol. 85, no. 3, pp. 457-481, 1990.

[77] D. London, R. L. Hervig, and G. B. Morgan VI, "Melt-vapor solubilities and elemental partitioning in peraluminous granitepegmatite systems: experimental results with Macusani glass at $200 \mathrm{MPa}$," Contributions to Mineralogy and Petrology, vol. 99, no. 3, pp. 360-373, 1988.

[78] V. I. Kovalenko, G. M. Tsareva, and M. Cuney, "Major-, trace elements and water in the magma of the Beauvoir rare metal granite, France (melt inclusion data)," Doklady Akademii Nauk, vol. 358, no. 5, pp. 667-671, 1998.

[79] G. P. Zaraisky, V. Korzhinskaya, and N. Kotova, "Experimental studies of $\mathrm{Ta}_{2} \mathrm{O}_{5}$ and columbite-tantalite solubility in fluoride solutions from 300 to $550^{\circ} \mathrm{C}$ and 50 to $100 \mathrm{MPa}$, Mineralogy and Petrology, vol. 99, no. 3-4, pp. 287-300, 2010.

[80] A. Timofeev, A. A. Migdisov, and A. E. Williams-Jones, "An experimental study of the solubility and speciation of niobium in fluoride-bearing aqueous solutions at elevated temperature," Geochimica et Cosmochimica Acta, vol. 158, pp. 103-111, 2015. 

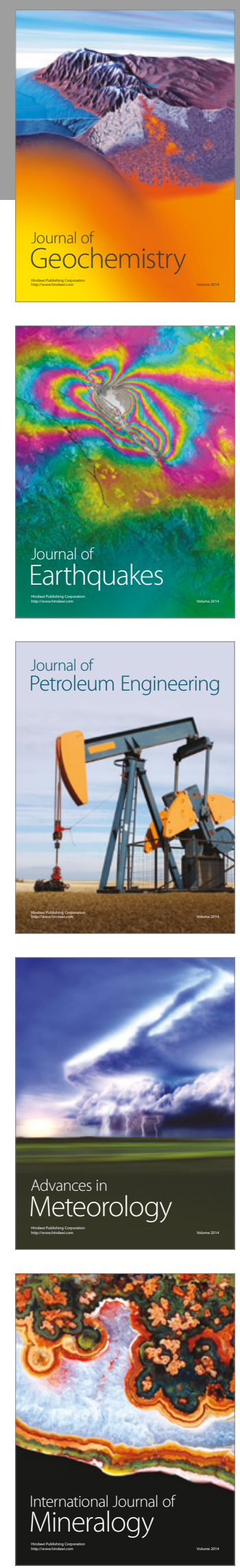
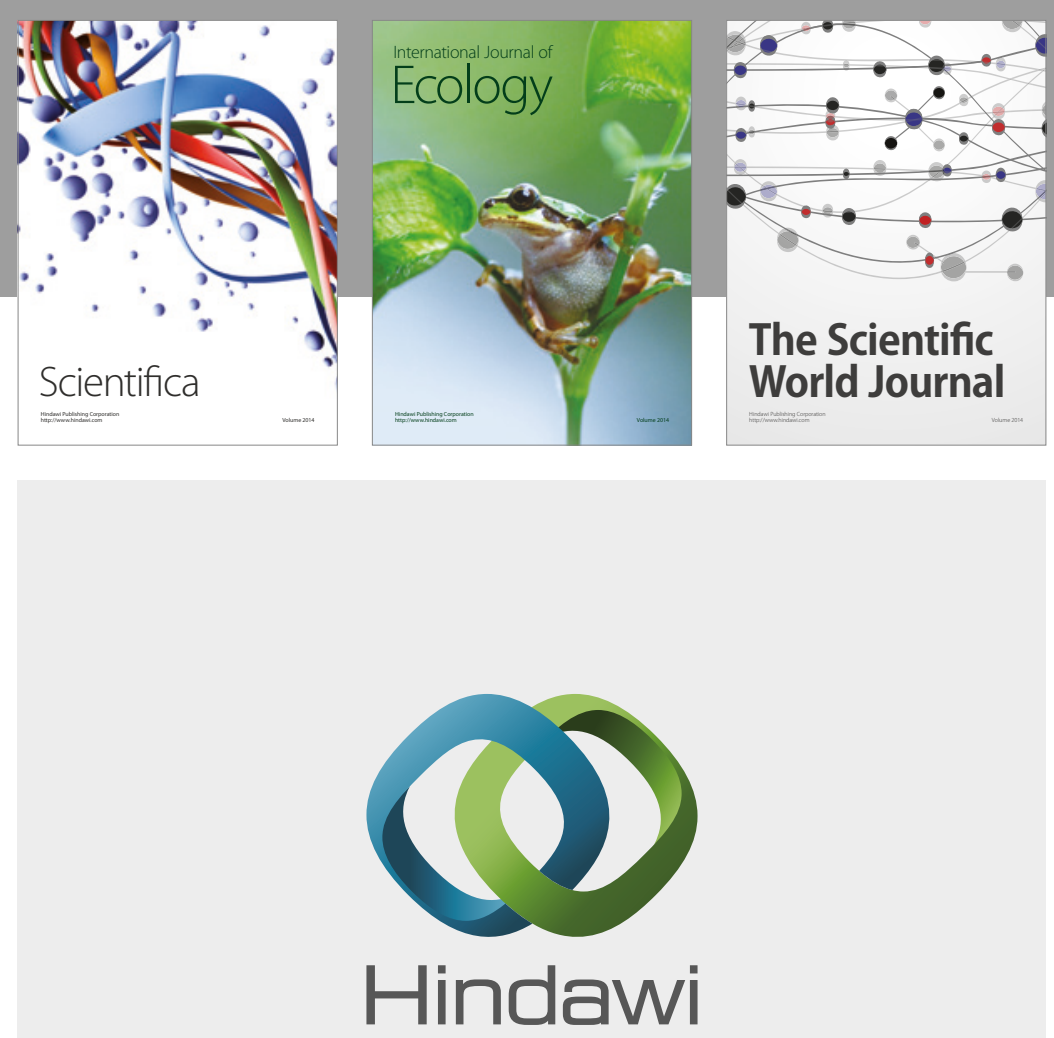

Submit your manuscripts at

https://www.hindawi.com
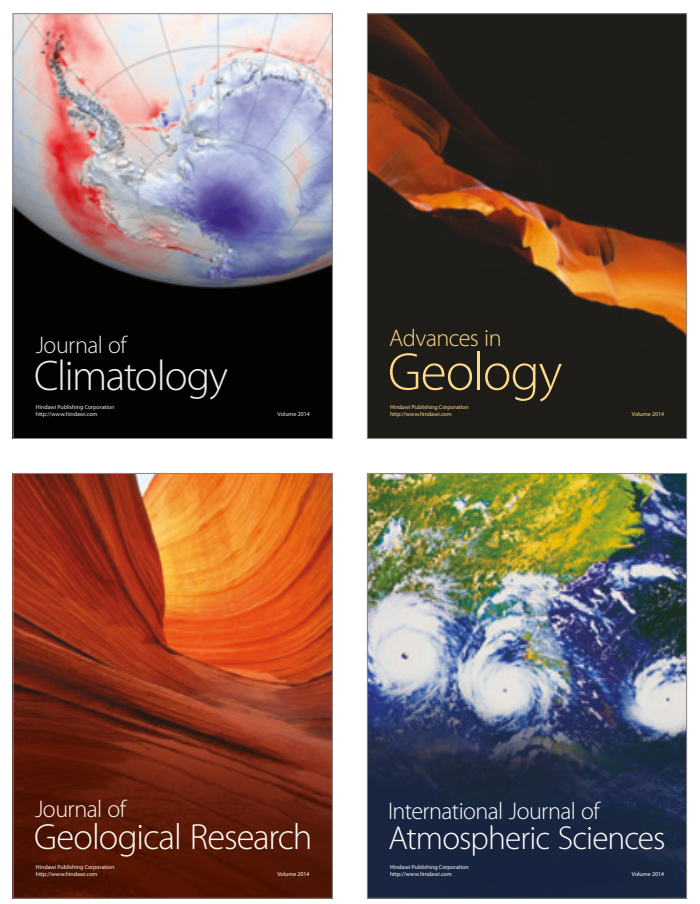

The Scientific

World Journal
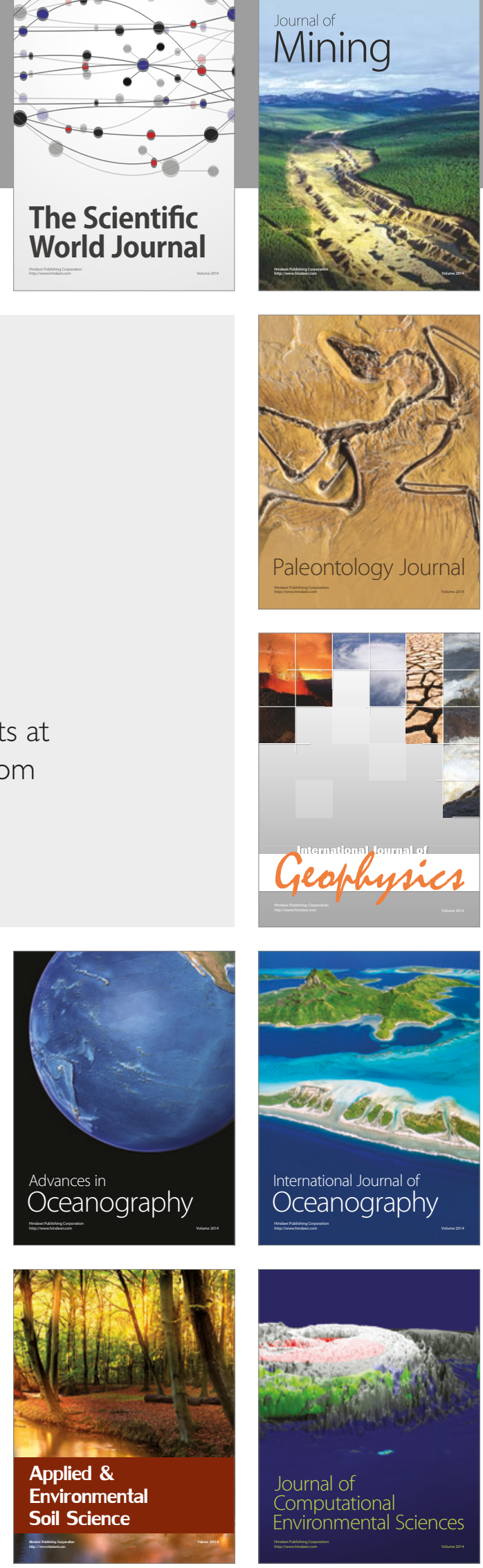